Article

\title{
Origin of Minerals and Elements in the Late Permian Coal Seams of the Shiping Mine, Sichuan, Southwestern China
}

\author{
Yangbing Luo * and Mianping Zheng \\ MLR Key Laboratory of Saline Lake Resources and Environments, Institute of Mineral Resources, \\ Chinese Academy of Geological Sciences (CAGS), Beijing 100037, China; mpzheng@126.com \\ * Correspondence: luoyangbing0319@gmail.com; Tel.: +86-10-6899-9837
}

Academic Editor: Thomas N. Kerestedjian

Received: 27 January 2016; Accepted: 13 July 2016; Published: 19 July 2016

\begin{abstract}
Volcanic layers in coal seams in southwestern China coalfields have received much attention given their significance in coal geology studies and their potential economic value. In this study, the mineralogical and geochemical compositions of C19 and C25 coal seams were examined, and the following findings were obtained. (1) Clay minerals in sample C19-r are argillized, and sedimentary layering is not observed. The acicular idiomorphic crystals of apatite and the phenocrysts of Ti-augite coexisting with magnetite in roof sample C19-r are common minerals in basaltic rock. The rare earth elements (REE) distribution pattern of C19-r, which is characterized by positive Eu anomalies and $\mathrm{M}$-REE enrichment, is the same as that of high-Ti basalt. The concentrations of $\mathrm{Ti}, \mathrm{V}, \mathrm{Co}, \mathrm{Cr}, \mathrm{Ni}$, $\mathrm{Cu}, \mathrm{Zn}, \mathrm{Nb}, \mathrm{Ta}, \mathrm{Zr}$, and $\mathrm{Hf}$ in C19-r are closer to those of high-Ti basalt. In conclusion, roof sample C19-r consists of tuffaceous clay, probably with a high-Ti mafic magma source. (2) The geochemical characteristics of the $\mathrm{C} 25$ coals are same as those reported for coal affected by alkali volcanic ash, enrichment in $\mathrm{Nb}, \mathrm{Ta}, \mathrm{Zr}, \mathrm{Hf}$, and REE, causing the $\mathrm{C} 25$ minable coal seams to have higher potential value. Such a vertical study of coals and host rocks could provide more information for coal-forming depositional environment analysis, for identification of volcanic eruption time and magma intrusion, and for facilitating stratigraphic subdivision and correlation.
\end{abstract}

Keywords: southeastern Sichuan; Late Permian; Shiping mine; volcanic layers in coal seams; high-Ti basalt

\section{Introduction}

Volcanic ash ejected from volcanoes falls into peat swamps and subsequently can form a thin and stable stratum in coal seams, which is usually "tonstein" and in some cases, occurs as roof and floor strata of coal seams [1,2]. These volcanic layers in coal seams get much attention as they can help to identify times of volcanic eruption and magma intrusion in this area, assess the coal-forming environments, and facilitate stratigraphic subdivision and correlation [1-8]. Moreover, some volcanic layers in the coal seams may contain valuable trace elements (such as rare earth elements, $\mathrm{Nb}, \mathrm{Ta}, \mathrm{Zr}$, $\mathrm{Hf}$, and $\mathrm{Ga}$ ) that could increase the potential value of the coal $[4,5]$. Consequently, host rocks (tonsteins, floor and roof) in coal seams related to volcanic ash are of great importance in coal geology $[2,3,6,7]$.

Volcanic activity frequently occurred in the Late Permian age in southwestern China [1,2,9-13], and volcanic ashes deposited in the peat-forming environment have been found in some coal seams in this area [1-5]. These volcanic layers found in southwest China can be divided into four types: felsic [2,14], alkali $[2,4,5,15,16]$, mafic [1,3], and dacitic [3]. It was reported that felsic and dacitic volcanic layers are common in Late Permian coal seams in southwestern China $[1,2,6,7]$. Alkali volcanic layer in the coal seams in southwestern China have attracted much attention given that coal 
seams affected by alkali volcanic ash are enriched in $\mathrm{Nb}$, Ta, $\mathrm{Zr}$, Hf, and REE $[2,4,5,15,16]$. However, because mafic eruptions generally do not form tuffs, mafic volcanic layers occur rarely in coal-bearing strata around the world and only a few have been found in the Late Permian coals from southwestern China $[1,3]$.

More attention has been paid to tonsteins in coal seams [5,16]; however, research on the roof and floor strata with a volcanic source was scarcely reported [3]. In this paper, geochemical and mineralogical characteristics of the roof sample in the C19 coal seam with a high-Ti mafic magma source were investigated. Variation in the element geochemistry and mineralogy of the C19 and C25 coals and floor sample in Late Permian from the Shiping mine, Sichuan, southwestern China was also described, with an emphasis on elements and minerals of volcanic origin in these coals and hosts rocks. Such a vertical study of coals and host rocks could provide more information for coal-forming depositional environments analysis, for identification of volcanic eruption time and magma intrusion, and for facilitating stratigraphic subdivision and correlation.

\section{Materials and Methods}

The Shiping mine is located in the southeastern part of Sichuan Province, southwestern China (Figure 1).

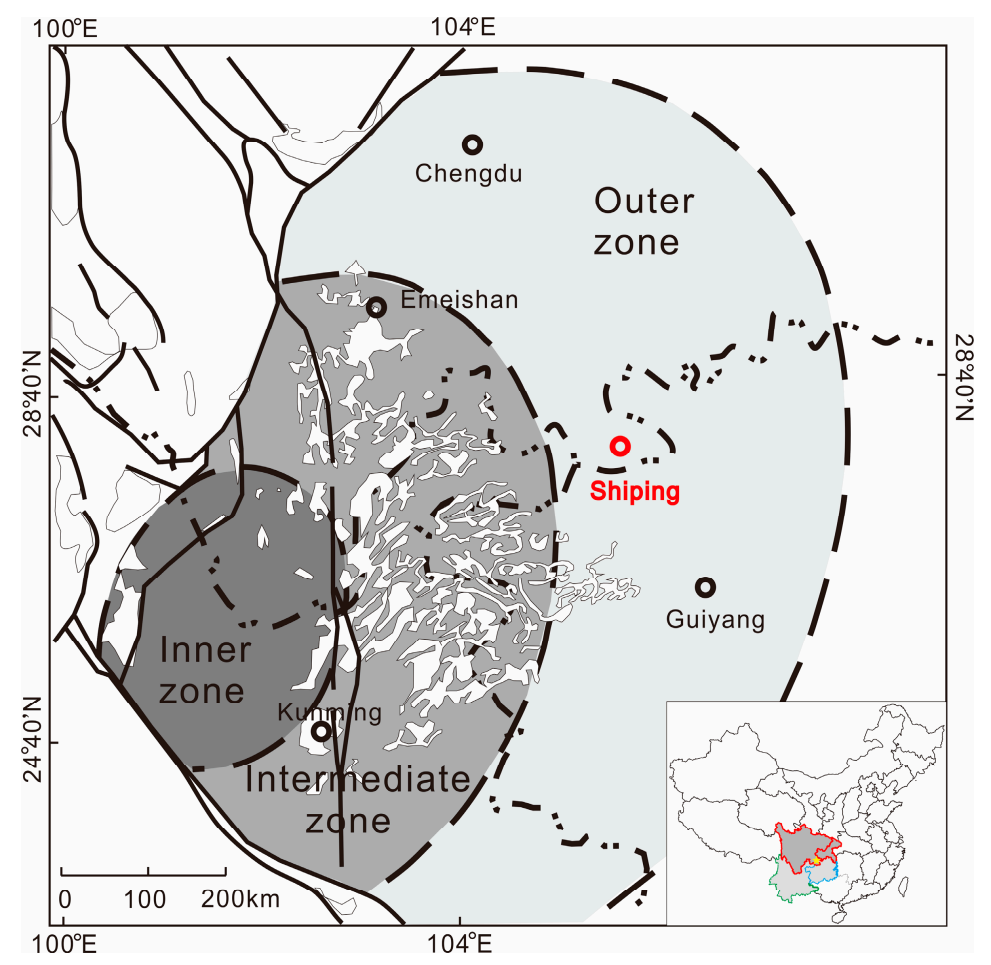

Figure 1. Distribution of Late Permian Emeishan basalts in southwestern China [13].

The sedimentary sequences in the Shiping mine include the Quaternary, Upper Triassic Xujiahe Formation, Middle Triassic Leikoupo Formation, Lower Triassic Jialingiiang and Feixianguan Formations, Upper Permian Changxing and Longtan Formations, Middle Permian Maokou and Xixia Formation, Lower Permian Liangshan Formation, and Silurian.

The coal-bearing sequence of the Shiping mine is the Late Permian Longtan Formation, which is composed mainly of mudstone, siltstone, sandstone, flint-bearing limestone, muddy sandstone, claystone, and six coal seams (Figure 2).

The Longtan Formation contains two major minable coal seams, namely the C19 and the C25. The C25 coal is the lowermost coal seam in the Late Permian strata of southwestern China. 
The thickness of the C25 coal seam is $0.80-1.30 \mathrm{~m}$. The C19 coal, with a thickness of $1.50-2.00 \mathrm{~m}$, is the lower-middle coal seam in the Late Permian strata of southwestern China.

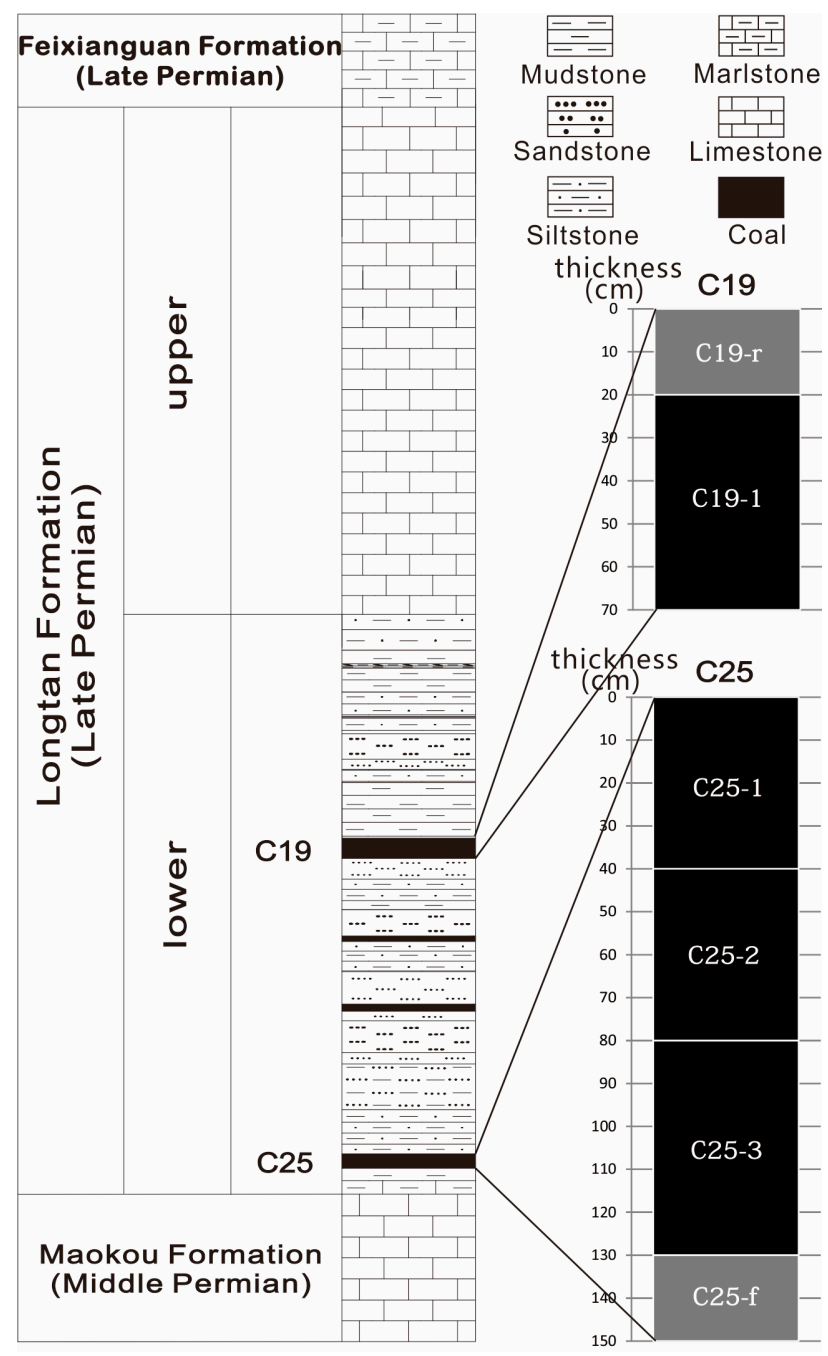

Figure 2. The sedimentary sequences of the Shiping mine.

\section{Samples and Analytical Procedures}

Six samples, including four coal bench samples (C19-1, C25-1, C25-2, and C25-3), one roof sample (C19-r), and one floor sample (C25-f), were taken from C19 and C25 coal seams mined at the coal working face of the Shiping mine (Figure 2). The identifications of all samples were shown in Figure 2. Each sample was cut over an area $10 \mathrm{~cm}$ wide and $10 \mathrm{~cm}$ deep. All samples were stored immediately in plastic bags to minimize contamination and oxidation.

Proximate analysis was conducted with ASTM Standards D3173-11 [17], D3174-11 [18], and D3175-11 [19]. Total sulfur and forms of sulfur were determined under ASTM Standards D3177-02 [20] and D2492-02 [21], respectively. Petrographic examination of the coals was performed under optical microscope following ASTM Standard D2797/D2797M-11a [22]. Mean random reflectance of vitrinite (percent $R_{0, r a n}$ ) was determined by using a Leica DM-4500P microscope (Leica Camera AG, Wetzlar, Germany). Maceral constituents were identified under white-light reflectance oil immersion microscopy.

A field emission-scanning electron microscope (FE-SEM, FEI Quanta ${ }^{\mathrm{TM}} 650$ FEG, FEI, Hillsboro, OR, USA), in conjunction with an EDAX energy-dispersive X-ray spectrometer (Genesis Apex 4, EDAX Inc., Mahwah, NJ, USA), was used to study morphology and microstructure and also to determine the 
distribution of some elements in the coal and rock samples. Low-temperature (oxygen-plasma) ashing (LTA) was performed, using an Emitech K1050X plasma asher (Quorum Inc., Lewes, UK), to remove organic matter in the coal prior to XRD analysis. The residues of this process were then analyzed by X-ray diffraction (XRD) using a D/max-2500/PC powder diffractometer (Rigaku, Tokyo, Japan) with Ni-filtered $\mathrm{Cu}-\mathrm{K} \alpha$ radiation and a scintillation detector. The XRD pattern was recorded over a $2 \theta$ interval of $2.6^{\circ}-70^{\circ}$, with a step size of $0.01^{\circ}$.

Concentrations of major element oxides in the samples (on ash basis; ashing temperature of $815^{\circ} \mathrm{C}$ ) were obtained by X-ray fluorescence (XRF) spectrometry. Mercury was determined by a Milestone DMA-80 Hg analyzer (Milestone, Sorisole, Italy). Fluorine analysis was conducted using ASTM Standard D5987-96 [23]. Inductively coupled plasma mass spectrometry (Thermo Fisher, Edmonton, AB, Canada, X series II ICP-MS) was used to determine the trace elements in the samples. All samples were digested using an UltraClave Microwave High Pressure Reactor (Milestone Inc., Shelton, CT, USA). Details for these coal-related sample digestion and ICP-MS analysis techniques are given by Dai et al. [1]. Arsenic and selenium were determined by ICP-MS, using collision cell technology (CCT), in order to avoid disturbance of polyatomic ions [24].

\section{Results}

\subsection{Coal Chemistry and Coal Petrology}

The vitrinite random reflectance $\left(\mathrm{R}_{\mathrm{O} \text {,ran }}\right.$ average $\left.2.21 \%\right)$ and the weighted average volatile matter ( $\mathrm{V}_{\text {daf }}$ average $15.98 \%$ ) of the coal bench samples (Table 1 ) indicate a bituminous coal according to the ASTM classification D388-12, 2012 [25]. The total sulfur content varies considerably between the C19 (0.59\%) and C25 (average 3.52\%) coals, and the coals can be classified as low-sulfur coal and high-sulfur coal, respectively, according to Chinese standard GB 15224.1-2004 [26].

Table 1. Bench thickness (cm), proximate analysis (\%), vitrinite random reflectance $(\%)$, and gross calorific values $(\mathrm{MJ} / \mathrm{kg}$ ) of coal benches from the Shiping mine.

\begin{tabular}{lcccccccccc}
\hline Samples & Thickness & $\mathbf{M}_{\mathbf{a d}}$ & $\mathbf{A}_{\mathbf{d}}$ & $\mathbf{V}_{\mathbf{d a f}}$ & $\mathbf{S}_{\mathbf{t}, \mathbf{d}}$ & $\mathbf{S}_{\mathbf{s}, \mathbf{d}}$ & $\mathbf{S}_{\mathbf{p}, \mathbf{d}}$ & $\mathbf{S}_{\mathbf{o}, \mathbf{d}}$ & $\mathbf{R}_{\mathbf{o}, \mathbf{r a n}}$ & $\mathbf{Q}_{\mathbf{g r}, \mathbf{d}}$ \\
\hline C19-1 & 50 & 1.75 & 17.42 & 9.14 & 0.59 & nd & nd & nd & 2.30 & 29.35 \\
C25-1 & 40 & 2.70 & 16.52 & 13.90 & 6.53 & 2.11 & 3.58 & 0.84 & 2.21 & 28.13 \\
C25-2 & 40 & 1.32 & 16.66 & 13.04 & 1.45 & 0.33 & 1.08 & 0.05 & 2.23 & 28.99 \\
C25-3 & 50 & 1.58 & 44.54 & 27.84 & 2.59 & 0.81 & 1.40 & 0.38 & 2.10 & 15.45 \\
\hline
\end{tabular}

$\mathrm{M}$, moisture; $\mathrm{A}$, ash yield; $\mathrm{V}$, volatile matter; $\mathrm{S}_{\mathrm{t}}$, total sulfur; ad, air-dry basis; $\mathrm{d}$, dry basis; daf, dry and ash-free basis; $R_{o, \text { ran, }}$ random reflectance; $\mathrm{Q}_{\mathrm{gr}, \mathrm{d}}$, gross calorific value, on a dry basis; nd, not detected.

The C19 and C25 coals contain abundant vitrinite (Table 2), with collodetrinite (Figure 3A) being the most abundant maceral, followed by collotelinite (Figure 3A), along with small proportions of telinite (Figure 3B) and vitrodetrinite (Figure 3C).

Inertinite macerals occur in lesser proportions (Table 2) and are dominated by semifusinite (Figure 3A), followed by macrinite (Figure 3D) and inertodetrinite (Figure 3A), with trace amounts of micrinite (Figure 3E) and fusinite (Figure 3F). The cell structures of the semifusinite and fusinite are better preserved and have swelled and deformed form (Figure 3A,F).

Table 2. Maceral composition (vol. \%; on mineral-free basis) of the Shiping coals.

\begin{tabular}{lccccccccccccc}
\hline Samples & Cd & Ct & T & Cg & Vd & T-V & F & Sf & Ma & Mi & Sc & Id & T-I \\
\hline C19-1 & 47.9 & 32.7 & 0.4 & bdl & 2.7 & 83.7 & 0.4 & 8.6 & 1.6 & 0.4 & bdl & 5.4 & 16.3 \\
C25-1 & 54.5 & 21.8 & bdl & bdl & 2.3 & 78.6 & bdl & 14.4 & 4.3 & bdl & bdl & 2.7 & 21.4 \\
C25-2 & 60.8 & 25.2 & 0.4 & bdl & 0.7 & 87.1 & bdl & 7.2 & 2.9 & bdl & bdl & 2.9 & 12.9 \\
C25-3 & 51.1 & 19.6 & 0.9 & bdl & 2.3 & 74.0 & bdl & 10.0 & 8.7 & 0.5 & bdl & 6.8 & 26.0 \\
\hline
\end{tabular}

$\mathrm{Cd}$, collodetrinite; $\mathrm{Ct}$, collotelinite; $\mathrm{T}$, telinite; $\mathrm{Cg}$, corpogelinite; $\mathrm{Vd}$, vitrodetrinite; $\mathrm{T}-\mathrm{V}$, total vitrinite; $\mathrm{F}$, fusinite; $\mathrm{Sf}$, semifusinite; $\mathrm{Ma}$, macrinite; $\mathrm{Mi}$, micrinite; Id, inertodetrinite; T-I, total inertinite. bdl, below detection limit. 

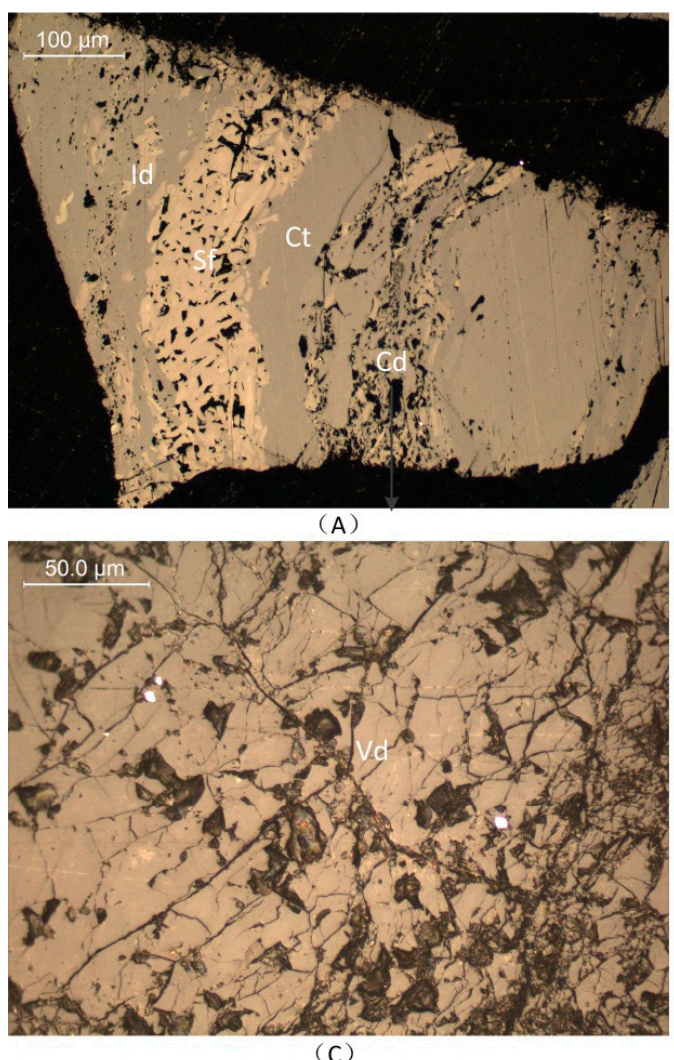

(C)

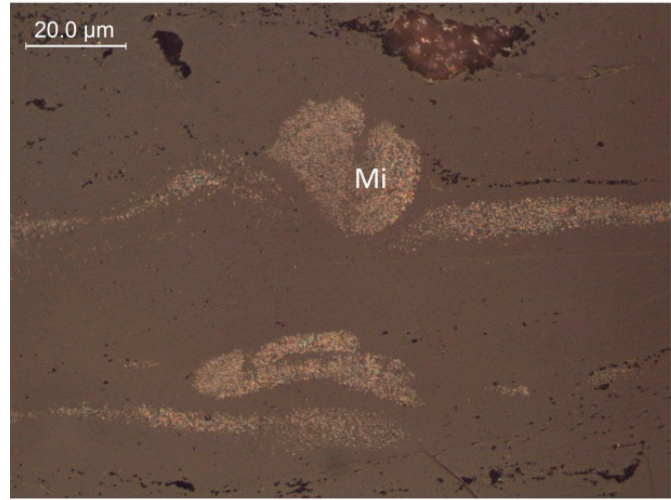

(E)

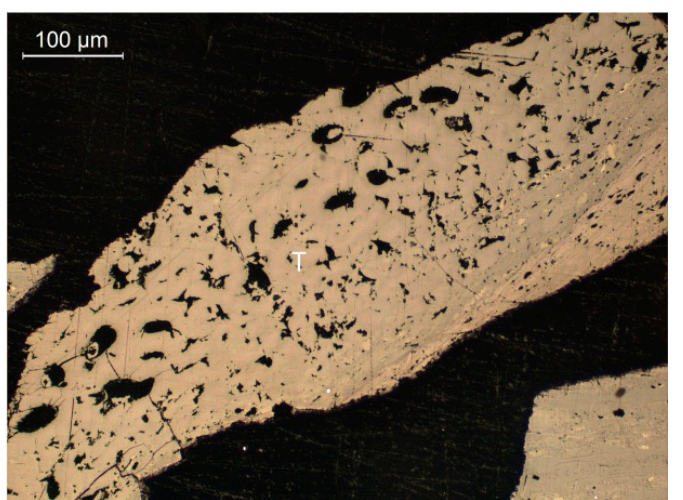

(B)

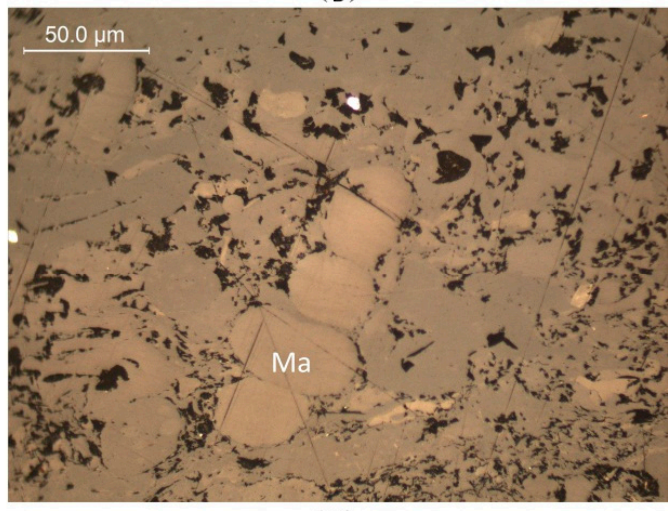

(D)

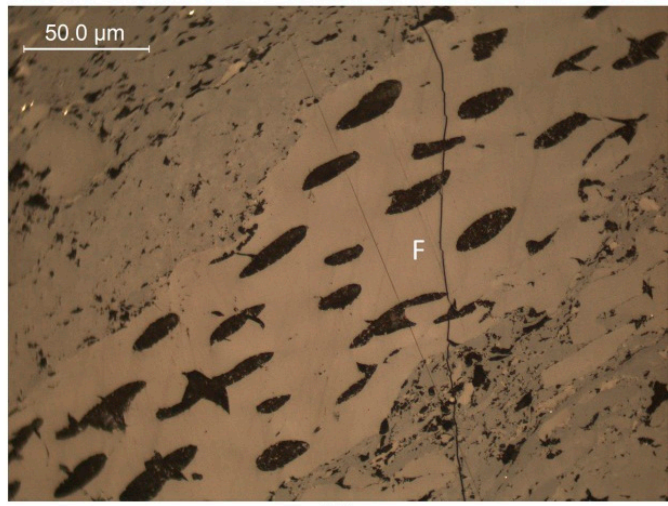

( $F)$

Figure 3. Macerals in the coal samples, reflected light, and oil immersion. (A) collodetrinite, collotelinite, semifusinite, and inertodetrinite in sample C25-1; (B) telinite in sample C25-2; (C) vitrodetrinite in sample C25-1; (D) fusinite with swelling cells in sample C25-3; (E) micrinite in sample C25-3; (F) macrinite in sample C25-3.

\subsection{Modes of Occurrence of Minerals}

The mineral compositions of the C19 and C25 coal low-temperature ashes (LTA), roof, and floor samples, as determined by XRD and Siroquant software, are listed in Table 3.

All samples contain clay minerals and pyrite (Table 3). The clay minerals in the C19 coal seams are mainly kaolinite, followed by illite and illite-smectite mixed layer clays. Kaolinite is the only clay mineral in the C25 coal seams. Kaolinite in the coals occurs as discrete particles (Figure 4A), cell-fillings (Figure 4B), and fracture-fillings (Figure 4A). Pyrite occurs as discrete particle aggregates (Figure 5A) and as cell fillings (Figure 5B), but it is present mainly as framboidal (Figure 5C) and needle-like forms together with marcasite (Figure 5D). 
Table 3. LTA yields of coal samples and mineral compositions (\%) of coal LTAs, partings, roofs, and floors determined by XRD and Siroquant.

\begin{tabular}{ccccccc}
\hline Minerals & C19-r & C19-1 & C25-1 & C25-2 & C25-3 & C25-f \\
\hline LTAs & - & 17.58 & 24.94 & 20.21 & 49.35 & - \\
Kaolinite & 34.5 & 34.8 & 51.2 & 27.6 & 65.5 & 80.3 \\
Illite & 9.8 & 15.5 & - & - & - & - \\
I/S mixed-layer & 26.6 & 1.6 & - & - & - & - \\
Quartz & 19.8 & 26.6 & 1.4 & - & - & - \\
Pyrite & 0.4 & 7.4 & 27.9 & 3 & 3.4 & 5.4 \\
Marcasite & - & 10.3 & - & - & - & - \\
Anatase & 4.9 & - & 3.1 & - & - & - \\
Rutile & - & - & 6.8 & - & - & - \\
Calcite & 0.4 & - & 7.3 & 66 & 28.4 & 4.1 \\
Siderite & 3 & - & - & - & - & - \\
Jarosite & 0.6 & - & - & - & - & 2 \\
Bassanite & - & 3.7 & 2.2 & 3.4 & 2.7 & - \\
Gypsum & - & - & - & - & - & 8.2 \\
\hline
\end{tabular}

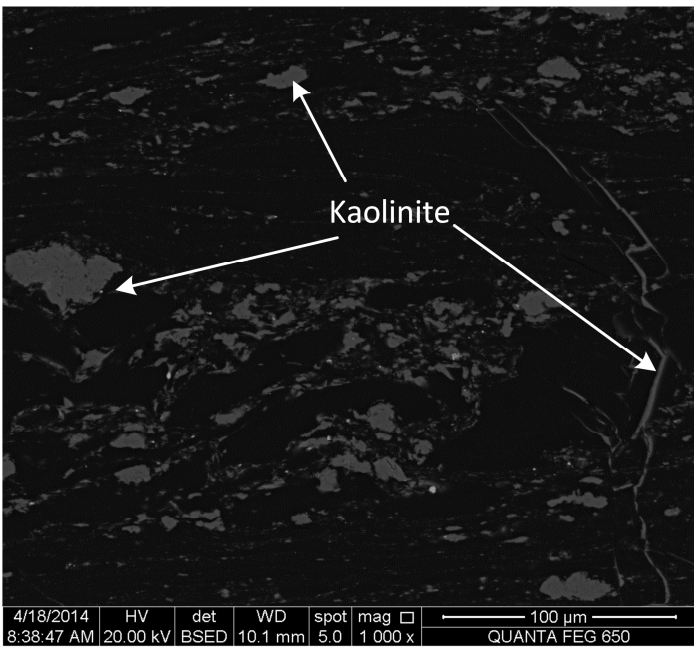

(A)

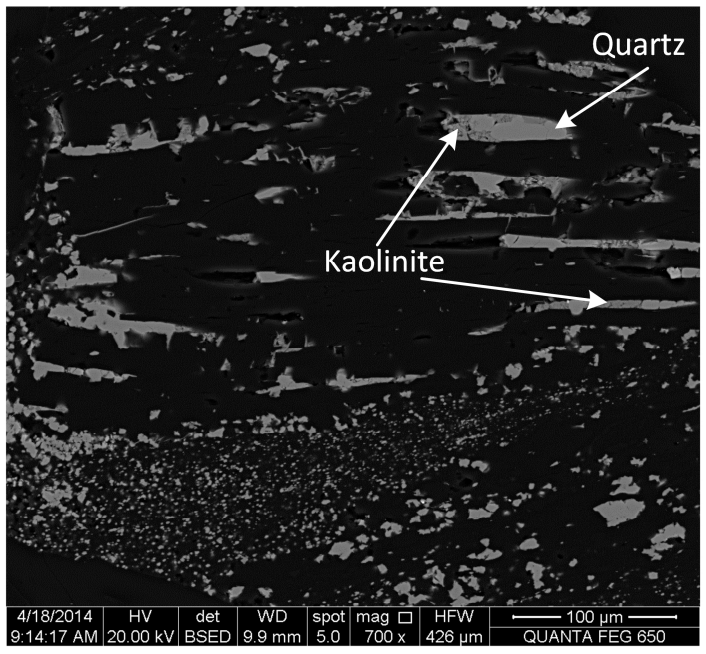

(B)

Figure 4. SEM back-scattered electron images of discrete particles and fracture-filling kaolinite in sample C19-1 (A); and cell-filling kaolinite and quartz in sample C25-2 (B).

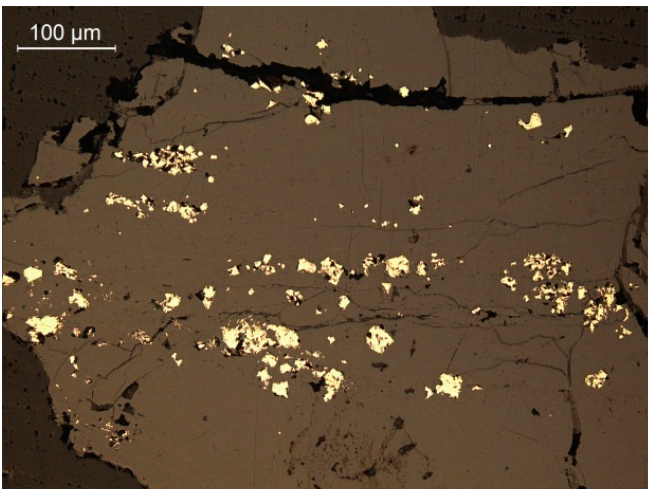

(A)

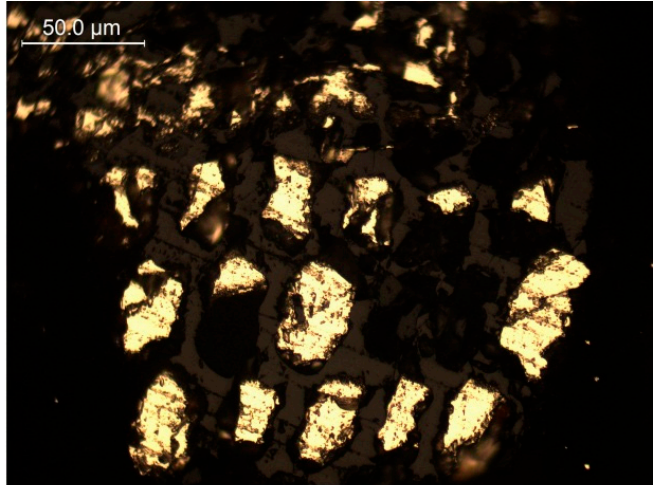

(B)

Figure 5. Cont. 


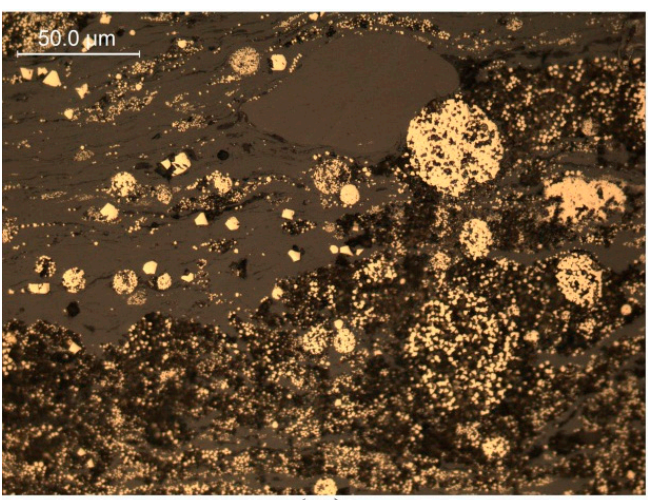

(C)

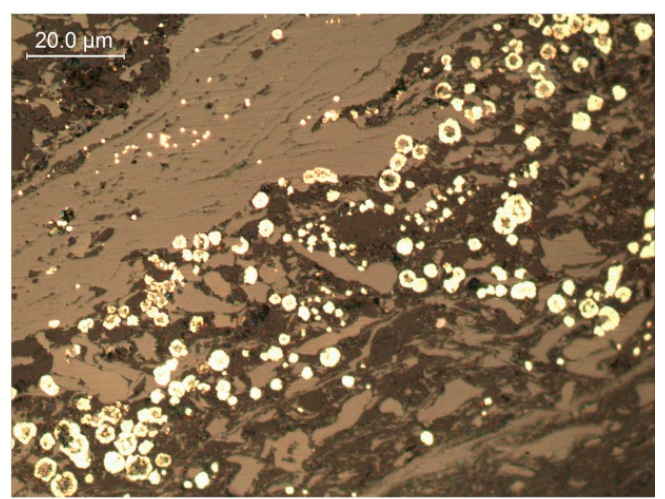

(D)

Figure 5. Pyrite in the C25 coal. (A) Particles of pyrite in sample C25-2; (B) cell-filling pyrite in sample C25-3; (C) framboidal pyrite in sample C25-3; (D) needle-like forms combined with marcasite in sample C25-3. Optical microscope, reflected light.

Quartz and marcasite are mainly contained in the C19 coal (Table 3). Quartz in coals occurs as discrete particles (Figure 6A), cell-fillings (Figure 4B), and fracture-fillings (Figure 6B), and marcasite occurs as needle-like forms together with pyrite (Figure 5D).

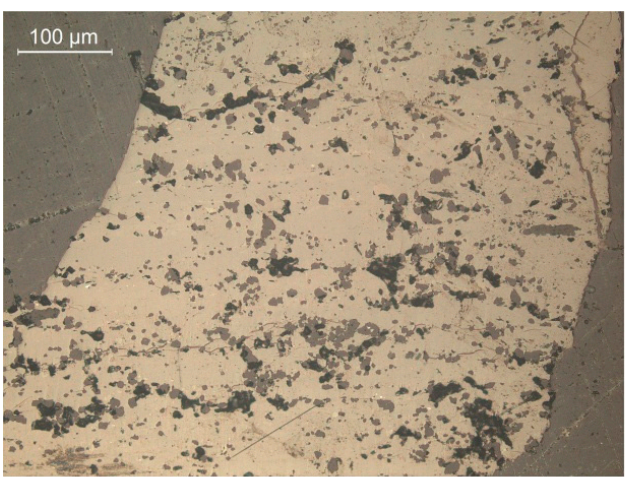

(A)

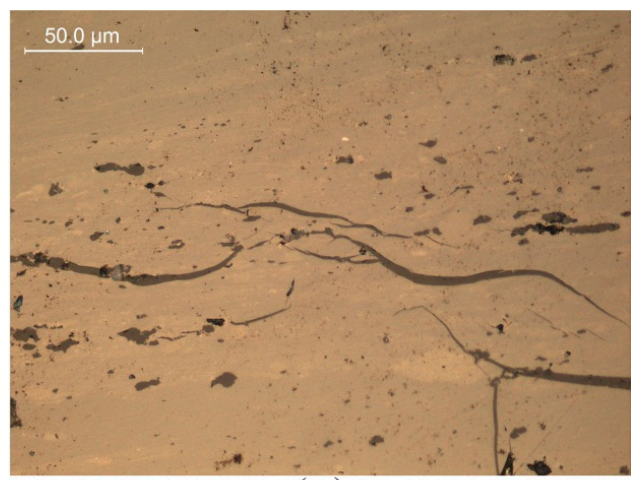

(B)

Figure 6. Quartz in sample C19-1. (A) Particles of quartz; (B) fracture-filling quartz. Optical microscope, reflected light.

Calcite, Ti-oxide minerals, and fluocerite are mainly contained in the C25 coals. The calcite in the C25 coals occurs as fracture fillings (Figure 7). As observed by SEM-EDS analysis of C25 coals, anatase, rutile (Figure $8 \mathrm{~A}$ ), and fluocerite (Figure $8 \mathrm{~B}$ ) are distributed in the kaolinite matrix.

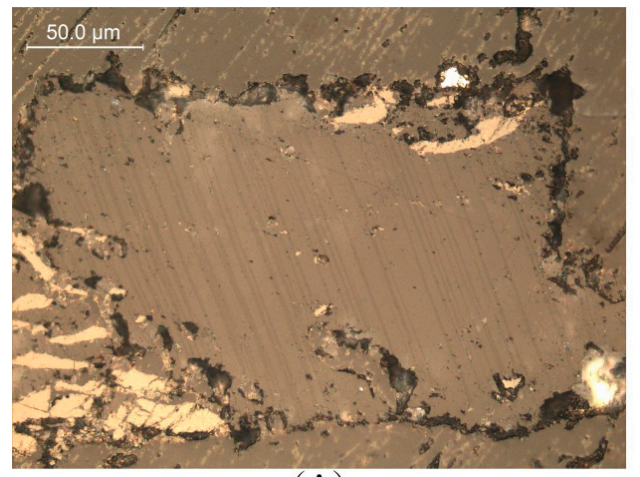

(A)

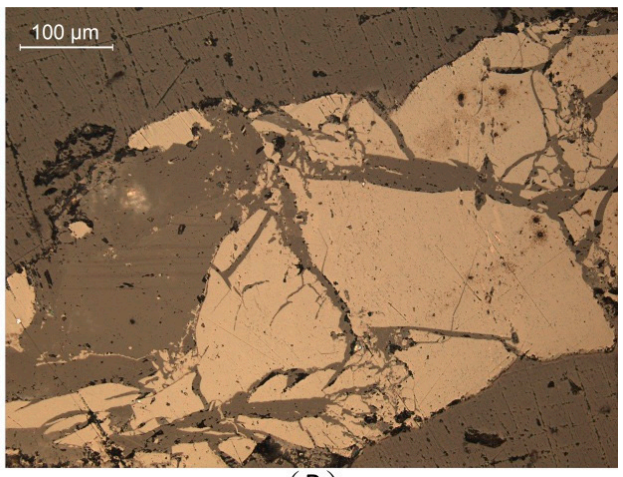

(B)

Figure 7. Calcite in C25-2. Optical microscope, reflected light. (A) Fracture-filling calcite and; (B) Fracture-filling calcite. 


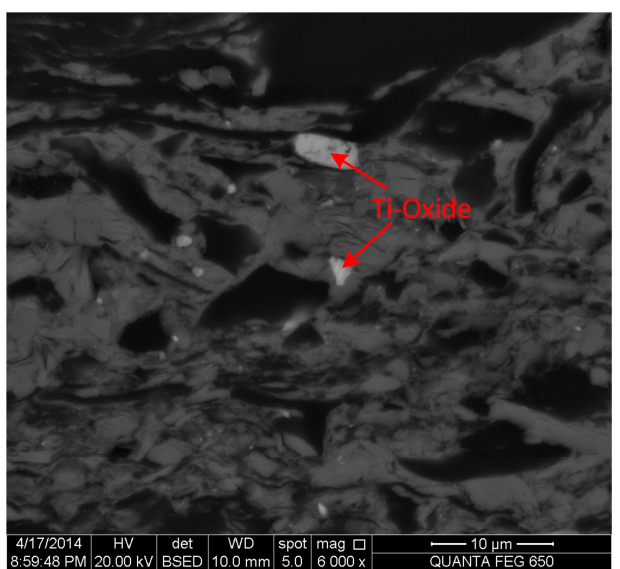

(A)

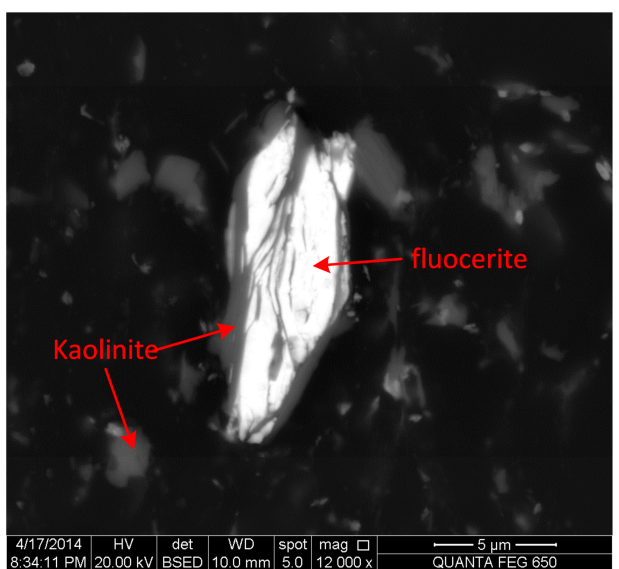

(B)

Figure 8. Back-scattered electron images of (A) Ti-oxide and (B) fluocerite in C25-3.

Chalcopyrite, titaniferous magnetite, apatite, and Ti-augite are present only in roof sample C19-r. Chalcopyrite occurs as fracture fillings (Figure 9A). Barite occurs in the form of discrete particles (Figure 9B). Titaniferous magnetite occurs as irregular granular. Apatite occurs as acicular idiomorphic crystals (Figure 9C). Ti-augite and rare magnetite occur as phenocrysts (Figure 9D). Marcasite was observed by SEM-EDS analysis in sample C25-f (Figure 10).

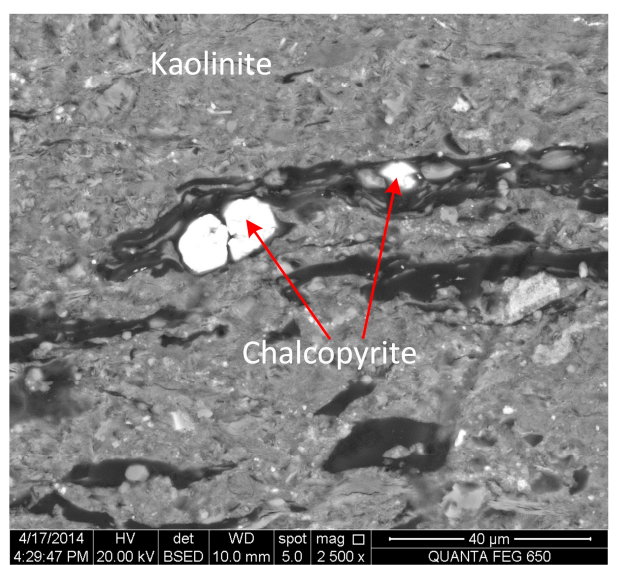

(A)

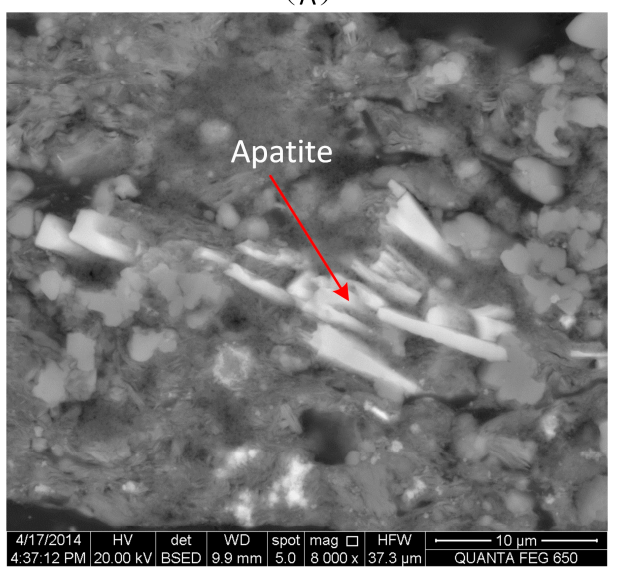

(C)

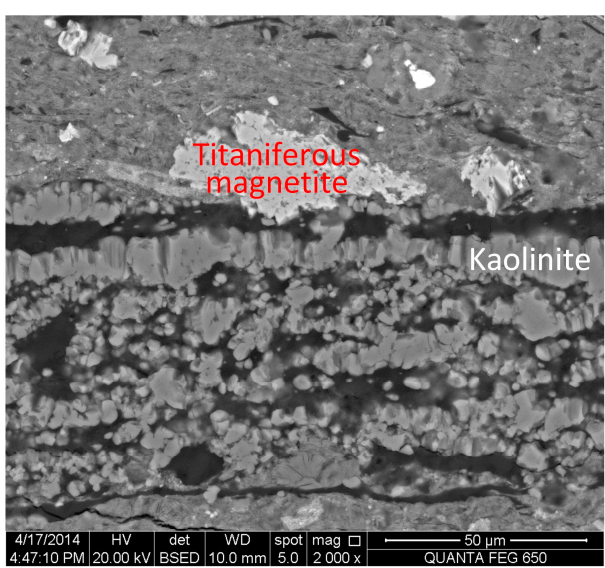

(B)

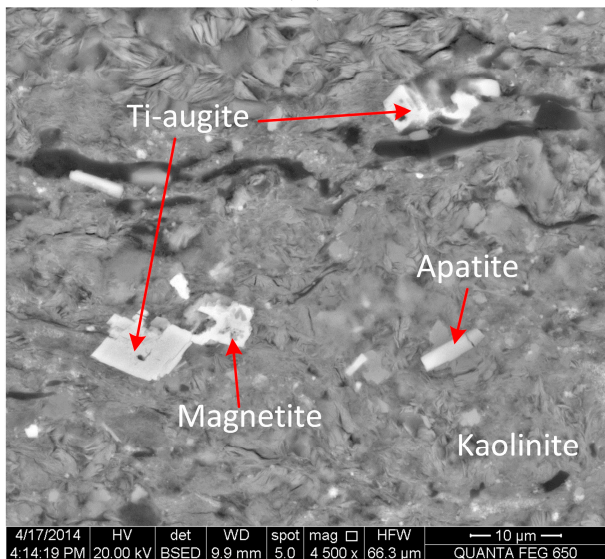

(D)

Figure 9. SEM back-scattered electron images of (A) fracture-filling chalcopyrite; (B) irregular granular of titaniferous magnetite and a vermicular texture in the kaolinite; (C) acicular idiomorphic crystals of apatite; and (D) phenocrysts of Ti-augite in C19-r. 


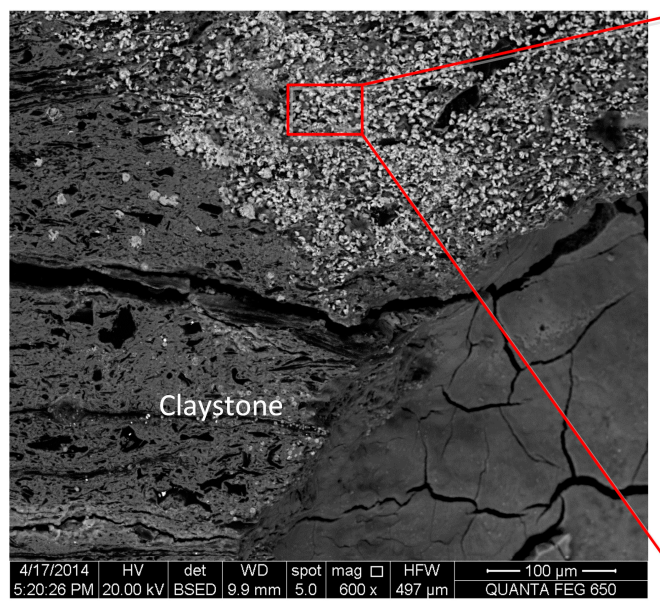

(A)

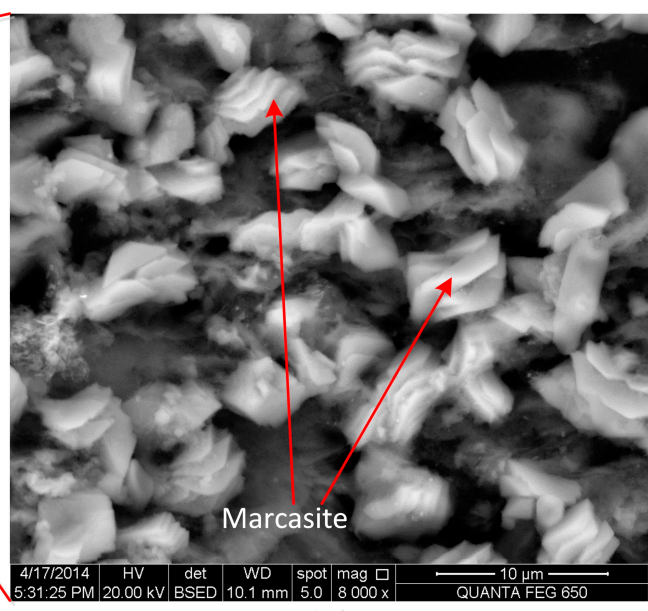

(B)

Figure 10. SEM back-scattered electron images of marcasite in C25-f. (A) Marcasite and claystone; (B) Marcasite.

\subsection{Concentration and Distribution of Major and Trace Elements}

\subsubsection{Major Element Oxides}

The element compositions of the C19 and C25 coals, roof, and floor are listed in Table 4.

Table 4. Bench thickness (cm), major element oxides (\%), loss on ignition (\%), and trace elements ( $\mu \mathrm{g} / \mathrm{g})$ in the Shiping coals and host rocks.

\begin{tabular}{|c|c|c|c|c|c|c|}
\hline Elements & C19-r & C19-1 & C25-1 & C25-2 & C25-3 & C25-f \\
\hline Thickness & - & 50 & 40 & 40 & 50 & - \\
\hline $\mathrm{SiO}_{2}$ & 43.4 & 13.5 & 4.75 & 4.20 & 16.1 & 25.5 \\
\hline $\mathrm{TiO}_{2}$ & 3.88 & 0.279 & 0.291 & 0.229 & 0.482 & 0.934 \\
\hline $\mathrm{Al}_{2} \mathrm{O}_{3}$ & 22.5 & 1.88 & 4.51 & 4.12 & 14.5 & 22.4 \\
\hline $\mathrm{Fe}_{2} \mathrm{O}_{3}$ & 1.90 & 0.337 & 5.50 & 1.40 & 2.70 & 4.49 \\
\hline $\mathrm{MnO}$ & 0.007 & 0.003 & 0.004 & 0.037 & 0.017 & 0.004 \\
\hline $\mathrm{MgO}$ & 0.363 & 0.096 & 0.066 & 0.064 & 0.176 & 0.192 \\
\hline $\mathrm{CaO}$ & 0.708 & 0.426 & 0.389 & 3.78 & 5.75 & 2.63 \\
\hline $\mathrm{Na}_{2} \mathrm{O}$ & 0.480 & 0.053 & 0.050 & 0.022 & 0.055 & 0.057 \\
\hline $\mathrm{K}_{2} \mathrm{O}$ & 1.15 & 0.017 & 0.066 & 0.031 & 0.122 & 0.228 \\
\hline $\mathrm{P}_{2} \mathrm{O}_{5}$ & 0.403 & 0.007 & 0.009 & 0.006 & 0.016 & 0.026 \\
\hline LOI & 24.6 & 82.9 & 83.9 & 83.6 & 56.2 & 39.8 \\
\hline $\mathrm{SiO}_{2} / \mathrm{Al}_{2} \mathrm{O}_{3}$ & 1.93 & 7.19 & 1.05 & 1.02 & 1.11 & 1.14 \\
\hline $\mathrm{Li}$ & 49.1 & 9.97 & 21.7 & 33.2 & 178 & 343 \\
\hline $\mathrm{Be}$ & 3.38 & 2.89 & 7.73 & 16.2 & 9.47 & 9.29 \\
\hline $\mathrm{F}$ & 787 & 36.8 & 77.2 & 52.4 & 342 & 480 \\
\hline $\mathrm{Sc}$ & 22.6 & 5.00 & 6.79 & 4.07 & 8.96 & 15.3 \\
\hline $\mathrm{V}$ & 331 & 38.5 & 61.0 & 26.3 & 646 & 2904 \\
\hline $\mathrm{Cr}$ & 118 & 12.7 & 24.1 & 13.8 & 282 & 1837 \\
\hline $\mathrm{Co}$ & 16.2 & 17.9 & 2.61 & 2.35 & 3.83 & 20.0 \\
\hline $\mathrm{Ni}$ & 36.9 & 34.6 & 14.8 & 9.65 & 46.2 & 166 \\
\hline $\mathrm{Cu}$ & 278 & 20.6 & 14.8 & 9.42 & 29.2 & 95.8 \\
\hline $\mathrm{Zn}$ & 300 & 13.9 & 20.4 & 14.7 & 80.6 & 71.5 \\
\hline $\mathrm{Ga}$ & 38.0 & 4.06 & 12.8 & 9.01 & 36.5 & 75.3 \\
\hline $\mathrm{Ge}$ & 2.47 & 0.93 & 3.79 & 8.62 & 10.3 & 4.80 \\
\hline As & 11.4 & 1.66 & 3.29 & 2.67 & 7.98 & 25.2 \\
\hline Se & 22.2 & 4.02 & 5.09 & 4.09 & 22.8 & 63.2 \\
\hline $\mathrm{Rb}$ & 33.7 & 0.496 & 1.53 & 0.554 & 3.43 & 6.02 \\
\hline $\mathrm{Sr}$ & 759 & 77.9 & 164 & 325 & 301 & 177 \\
\hline
\end{tabular}


Table 4. Cont.

\begin{tabular}{|c|c|c|c|c|c|c|}
\hline Elements & C19-r & C19-1 & C25-1 & C25-2 & C25-3 & C25-f \\
\hline $\mathrm{Y}$ & 69.2 & 10.6 & 20.2 & 17.1 & 197 & 137 \\
\hline $\mathrm{Zr}$ & 613 & 82.7 & 228 & 125 & 1744 & 1648 \\
\hline $\mathrm{Nb}$ & 91.3 & 11.4 & 17.0 & 19.1 & 192 & 131 \\
\hline Mo & 20.0 & 0.868 & 1.31 & 0.707 & 3.82 & 24.2 \\
\hline $\mathrm{Cd}$ & 1.63 & 0.210 & 0.666 & 0.432 & 14.6 & 17.9 \\
\hline In & 0.183 & 0.046 & 0.020 & 0.045 & 0.226 & 0.563 \\
\hline Sn & 4.88 & 0.831 & 1.12 & 1.18 & 7.89 & 12.6 \\
\hline $\mathrm{Sb}$ & 1.26 & 0.097 & 0.251 & 0.177 & 0.966 & 7.63 \\
\hline Cs & 4.07 & 0.071 & 0.206 & 0.069 & 1.06 & 1.82 \\
\hline $\mathrm{Ba}$ & 223 & 13.5 & 18.3 & 9.47 & 46.3 & 78.0 \\
\hline REE & 703 & 40.7 & 73.8 & 124 & 1037 & 1323 \\
\hline $\mathrm{La}$ & 127 & 5.48 & 11.4 & 25.4 & 173 & 221 \\
\hline $\mathrm{Ce}$ & 274 & 11.7 & 19.5 & 44.3 & 322 & 533 \\
\hline $\operatorname{Pr}$ & 29.8 & 1.29 & 2.13 & 5.21 & 42.5 & 54.6 \\
\hline $\mathrm{Nd}$ & 117 & 4.72 & 7.72 & 18.1 & 159 & 224 \\
\hline Sm & 26.0 & 1.08 & 1.77 & 3.15 & 30.6 & 39.8 \\
\hline $\mathrm{Eu}$ & 6.45 & 0.254 & 0.416 & 0.436 & 2.82 & 3.26 \\
\hline $\mathrm{Gd}$ & 22.5 & 1.34 & 2.32 & 3.44 & 32.2 & 36.5 \\
\hline $\mathrm{Tb}$ & 2.76 & 0.222 & 0.438 & 0.493 & 4.87 & 5.07 \\
\hline Dy & 13.1 & 1.39 & 2.97 & 2.67 & 28.6 & 27.3 \\
\hline Ho & 2.46 & 0.313 & 0.636 & 0.535 & 6.01 & 5.58 \\
\hline Er & 6.35 & 0.969 & 1.92 & 1.46 & 17.5 & 15.6 \\
\hline $\mathrm{Tm}$ & 0.878 & 0.149 & 0.282 & 0.203 & 2.50 & 2.37 \\
\hline $\mathrm{Yb}$ & 5.48 & 0.994 & 1.85 & 1.26 & 16.1 & 15.6 \\
\hline $\mathrm{Lu}$ & 0.804 & 0.159 & 0.280 & 0.189 & 2.35 & 2.39 \\
\hline $\mathrm{Hf}$ & 13.7 & 1.78 & 3.51 & 3.01 & 38.2 & 28.0 \\
\hline $\mathrm{Ta}$ & 5.43 & 0.619 & 0.835 & 0.930 & 5.16 & 5.93 \\
\hline $\mathrm{Hg}(\mathrm{ppb})$ & 59.8 & 19.5 & 396 & 197 & 372 & 621 \\
\hline $\mathrm{Tl}$ & 0.077 & 0.004 & 0.188 & 0.045 & 0.083 & 0.115 \\
\hline $\mathrm{Pb}$ & 66.6 & 6.18 & 12.5 & 2.19 & 12.6 & 29.1 \\
\hline $\mathrm{Bi}$ & 0.164 & 0.212 & 0.146 & 0.205 & 0.427 & 0.598 \\
\hline Th & 17.8 & 3.20 & 4.19 & 4.61 & 16.9 & 28.0 \\
\hline $\mathrm{U}$ & 4.34 & 0.753 & 2.33 & 1.30 & 155 & 505 \\
\hline
\end{tabular}

The percentages of $\mathrm{Al}_{2} \mathrm{O}_{3}$ and $\mathrm{CaO}$ in the $\mathrm{C} 19$ coal (C19-1) are lower than those in the more normal Chinese coals reported by Dai et al. [27]. The $\mathrm{SiO}_{2} / \mathrm{Al}_{2} \mathrm{O}_{3}$ ratio of sample C19-1 (7.19 on average) is much higher than that of other Chinese coals (1.42) [27] and also than the theoretical ratio for kaolinite (1.18), indicating free $\mathrm{SiO}_{2}$ in the coal. The percentages of other major element oxides, however, are either lower than or close to those in common Chinese coals.

The percentages of $\mathrm{Al}_{2} \mathrm{O}_{3}$ and $\mathrm{CaO}$ in the $\mathrm{C} 25$ coals are higher than those in the more normal Chinese coals reported by Dai et al. [27]. The percentages of other major element oxides, however, are either lower than or close to those in common Chinese coals. The $\mathrm{SiO}_{2} / \mathrm{Al}_{2} \mathrm{O}_{3}$ ratio of the $\mathrm{C} 25$ coals (1.06 on average) is lower than that of other Chinese coals (1.42) [27], and also than the theoretical ratio for kaolinite (1.18), indicating no free $\mathrm{SiO}_{2}$ in the coal.

It should be noted that the percentages of $\mathrm{TiO}_{2}$ are high in roof sample C19-r (3.88\%) but low in the $\mathrm{C} 19$ coal, $\mathrm{C} 25$ coals, and the floor sample (sample C25-f) (0.23-0.93\%). Oxides $\mathrm{SiO}_{2}, \mathrm{TiO}_{2}, \mathrm{Al}_{2} \mathrm{O}_{3}$, $\mathrm{MgO}, \mathrm{Na}_{2} \mathrm{O}, \mathrm{K}_{2} \mathrm{O}$, and $\mathrm{P}_{2} \mathrm{O}_{5}$ show a pattern of vertical variation the same as that of the ash yield through the seam section (Figure 11). 


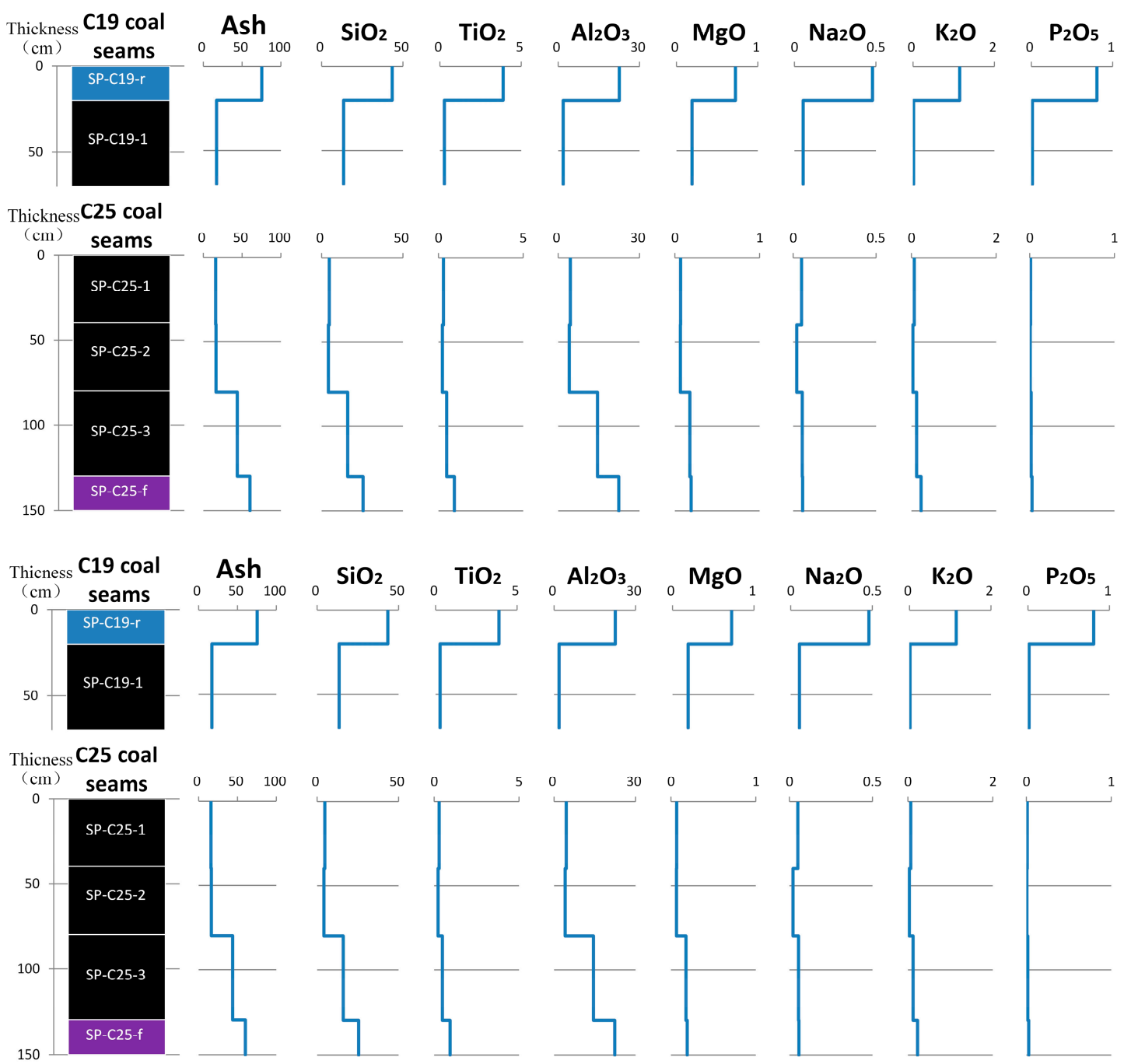

Figure 11. Variations of ash yield and selected major elements (\%) through the roof, coal seam, and floor section of the Shiping C19 and C25 coal.

\subsubsection{Trace Elements}

Trace elements in most of the coal samples of this study are lower than or close to those of hard coals of the world [28]. However, a large number of trace elements are enriched in sample C25-3 (Figure 12).

Compared to the average for hard coals of the world [28] and based on the trace-element enrichment classification [29], a large number of trace elements are depleted in samples C19-1, C25-1, and C25-2. The trace elements with a concentration coefficient $(C C=$ ratio of element concentration in Shiping coals/concentration hard coals of the world [28]) $<0.5$ include As, $\mathrm{Rb}, \mathrm{Sb}, \mathrm{Cs}, \mathrm{Ba}, \mathrm{Tl}$, and Bi. Only Zr in sample C25-1 $(5<\mathrm{CC}<10)$ and Be in sample C25-2 $(5<\mathrm{CC}<10)$ are enriched.

Compared to the average for hard coals of the world [28], a large number of trace elements, including $\mathrm{Li}, \mathrm{V}, \mathrm{Cr}, \mathrm{Se}, \mathrm{Zr}, \mathrm{Nb}, \mathrm{Cd}, \mathrm{REE}, \mathrm{Hf}, \mathrm{Ta}$, and $\mathrm{U}$, are enriched in C25-3 (CC > 10). Trace elements with a CC of 5-10 include Ga, In, Sn, and Th. Many other elements, including Be, F, Sc, Ni, Zn, Ge, Sr, and $\mathrm{Hg}$, are slightly enriched $(\mathrm{CC}=2-5)$ in the coal. The concentrations of the remaining elements are depleted or close to the average for hard coals of the world [28]. 

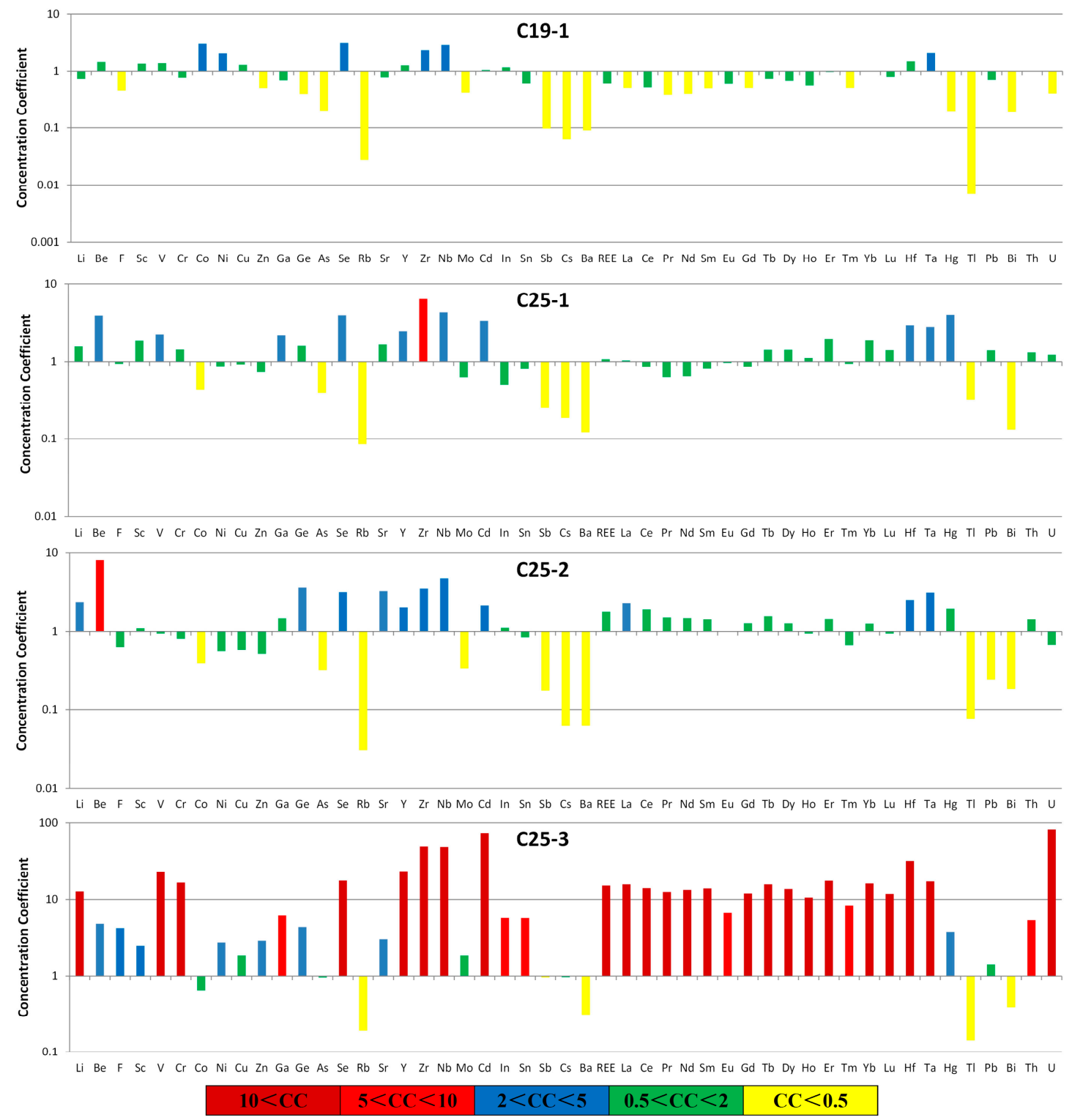

Figure 12. Concentration coefficients (CCs) of trace elements in the Shiping coals, normalized by average trace element concentrations in hard coals of the world [28] and based on the trace-element enrichment classification [29].

Compared to the average for the world clay [30] (Figure 13), trace elements Se and Mo are enriched in roof sample C19-r (CC > 10). Trace elements with a CC of 5-10 include $\mathrm{Cu}, \mathrm{Nb}$, and Eu. Many other elements, including $\mathrm{Rb}, \mathrm{Cs}, \mathrm{Ba}, \mathrm{Tl}$, and $\mathrm{Bi}$ are depleted $(\mathrm{CC}<0.5)$ in $\mathrm{C} 19-\mathrm{r}$. The concentrations of the remaining elements are slightly enriched $(C C=2-5)$ or close to $(C C=0.5-2)$ the average for world clay [30].

Compared to the average for the world clay [30] (Figure 13), a large number of trace elements, including $\mathrm{V}, \mathrm{Cr}, \mathrm{Se}, \mathrm{Nb}, \mathrm{Mo}, \mathrm{Cd}$, and $\mathrm{U}$, are enriched in floor sample $\mathrm{C} 25-\mathrm{f}(\mathrm{CC}>10)$. Trace elements with a CC of 5-10 include $\mathrm{Li}, \mathrm{Zr}, \mathrm{In}, \mathrm{Sb}, \mathrm{REE}, \mathrm{Hf}, \mathrm{Ta}$, and $\mathrm{Hg}$. Some elements, including $\mathrm{Rb}, \mathrm{Cs}, \mathrm{Ba}$, and $\mathrm{Tl}$, are depleted $(\mathrm{CC}<0.5)$ in sample $\mathrm{C} 25-\mathrm{f}$. The concentrations of the remaining elements are slightly enriched $(C C=2-5)$ or close to $(C C=0.5-2)$ the average for world clay [30]. 


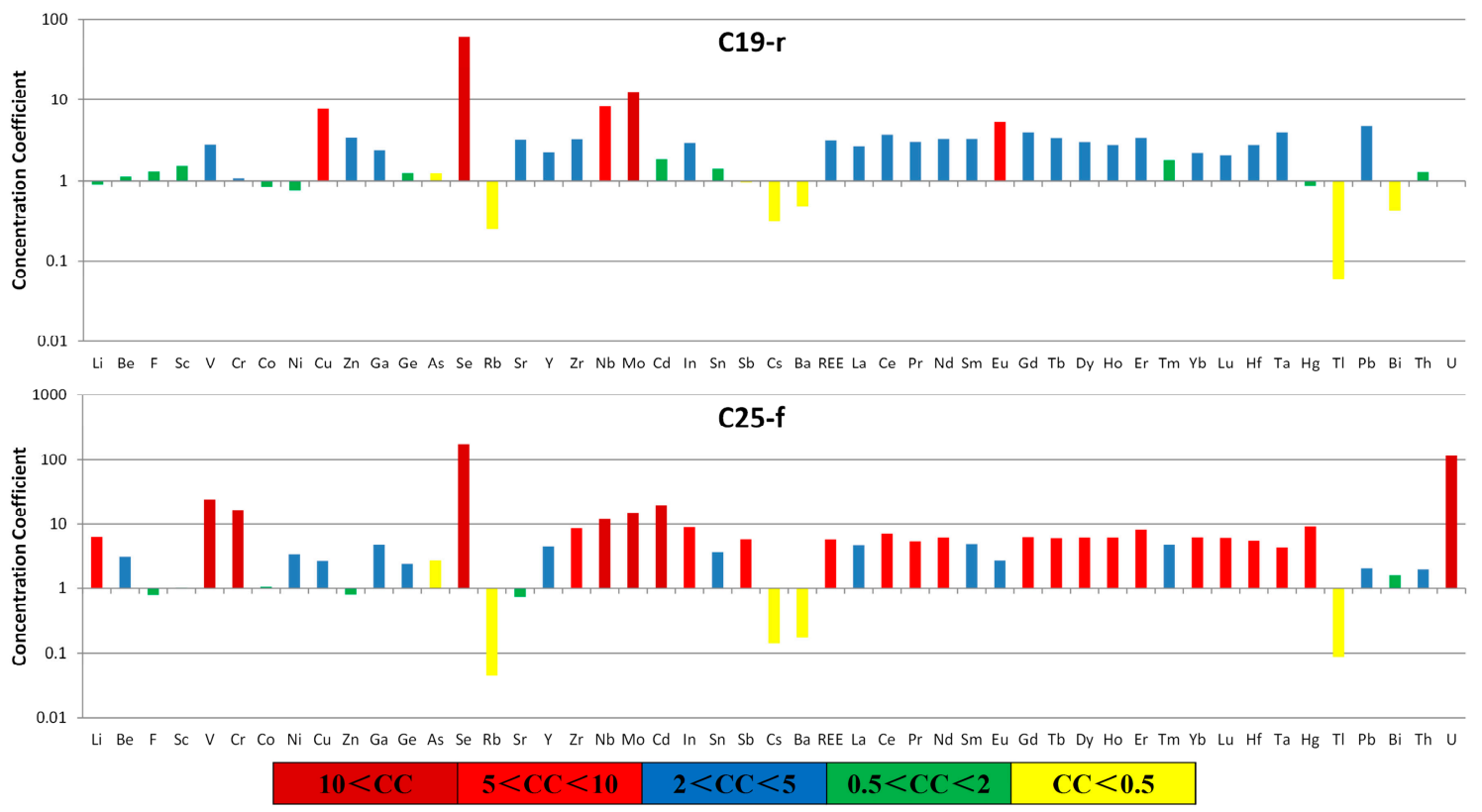

Figure 13. Concentration coefficients (CCs) of trace elements in the Shiping roof and floor samples, normalized by average trace element concentrations in clay of the world [30].

\subsubsection{Rare Earth Elements}

A threefold classification of rare earth elements [31] was used in this study. By comparison with the upper continental crust (UCC), three enrichment types were identified: L-REE (light REE; $\mathrm{La}_{N} / \mathrm{Lu}_{N}>1$ ), M-REE (medium REE; $\mathrm{La}_{N} / \mathrm{Sm}_{\mathrm{N}}<1, \mathrm{Gd}_{\mathrm{N}} / \mathrm{Lu}_{\mathrm{N}}>1$ ), and H-REE (heavy REE; $\mathrm{La}_{\mathrm{N}} / \mathrm{Lu}_{\mathrm{N}}<1$ ) [31].

The REE enrichment patterns in the C19-1 and C25-1 coal benches are characterized by weak Eu anomalies and H- and M-REE enrichment (Figure 14A). The REE enrichment patterns in sample C25-2 and C25-3 coal benches are characterized by strong negative Eu anomalies and M-REE enrichment (Figure 14B,C).

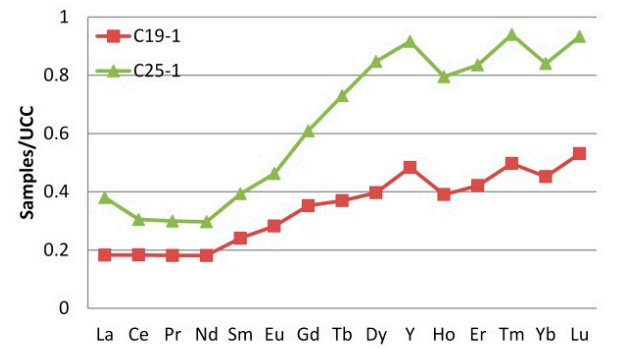

(A)

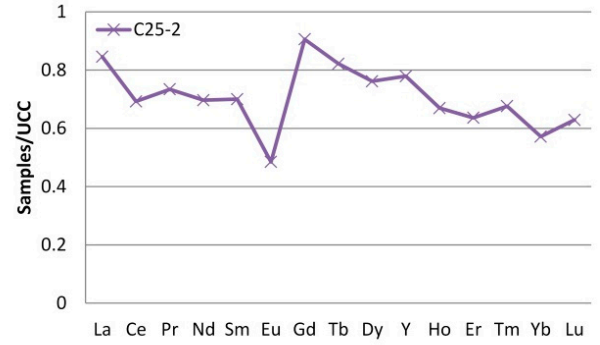

(B)

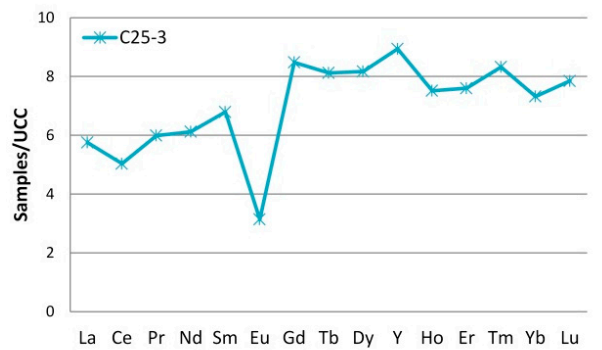

(C)

Figure 14. Distribution patterns of REE in the coal samples from the Shiping mine. REE are normalized by Upper Continental Crust (UCC) [32]. (A) Distribution patterns of REE in sample C19-1 and C25-1; (B) Distribution patterns of REE in sample C25-2; (C) Distribution patterns of REE in sample C25-3. 
The REE enrichment patterns in the roof sample C19-r (Figure 15A) are characterized by positive Eu anomalies and M-REE enrichment. Floor sample C25-f has the same REE enrichment patterns as the $\mathrm{C} 25$ coals (Figure 15B), which are characterized by strong negative Eu anomalies and M-REE enrichment.
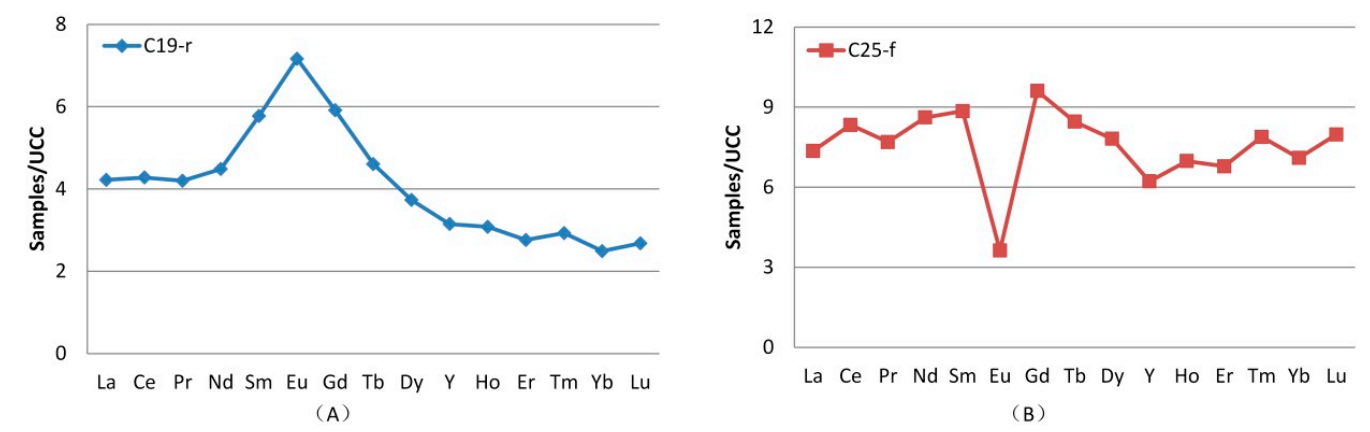

Figure 15. Distribution patterns of REE in the roof and floor samples from the Shiping mine. REE are normalized by Upper Continental Crust (UCC) [32]. (A) Distribution patterns of REE in sample C19-r; (B) Distribution patterns of REE in sample C25-f.

\section{Discussion}

A number of volcanic layers [33-35] and dispersed volcanic ashes in organic matter of coal seams [36-40] have been observed in the southwestern China coalfield, and these volcanic layers can be divided into four types: felsic, alkali, mafic, and dacitic $[1,2,10]$. In this paper, we have discussed the characteristics of the elements and minerals in the C19 and C25 coal seams, which are affected by different types of volcanic activity.

\subsection{C19 Coal Seam and Basalt}

The petrological characteristics of roof sample C19-r are different from those of other normal roof deposits. The clay minerals in C19-r are argillized (Figure 9A,D), and sedimentary layering is not observed (Figure 16), indicating that roof sample C19-r probably is a tuffaceous clay.

The contents of kaolinite, Illite, I/S, etc. are the same as in the floors of the C2 and C3 Coals in Xinde Mine, Xuanwei, eastern Yunnan, China [3]. These floor strata are identified as fully argillized, fine-grained, tuffaceous clays with high-Ti mafic magma source [3].

A vermicular texture in the kaolinite of roof sample C19-r (Figure 9B) is often used as an indicator of a volcanic origin [2,3,41-43]. The acicular idiomorphic crystals of apatite and the phenocrysts of Ti-augite coexisting with magnetite in roof sample C19-r (Figure 9C,D) are common minerals in basaltic rock [2,12,44-46]. Irregular granular titaniferous magnetite in C19-r (Figure 9B) is a typical mineral in basalt [47-50]. All the crystal modes of minerals indicate that roof sample C19-r has a high-Ti basalt origin.

The major elements $\mathrm{TiO}_{2} / \mathrm{Al}_{2} \mathrm{O}_{3}$ ratio can indicate the acidic/basic/intermediate property of deposits, including normal sedimentary rocks, coal seam, and tonsteins $[5,6,14,51-60]$. The $\mathrm{TiO}_{2} / \mathrm{Al}_{2} \mathrm{O}_{3}$ ratios are $>0.08$ for mafic, $0.08-0.02$ for intermediate, and $<0.02$ for silicic rocks [1-3]. The $\mathrm{TiO}_{2} / \mathrm{Al}_{2} \mathrm{O}_{3}$ ratio for $\mathrm{C} 19-\mathrm{r}$ is 0.17 , indicating a mafic origin. Trace elements, including $\mathrm{V}, \mathrm{Co}, \mathrm{Cr}, \mathrm{Ni}, \mathrm{Cu}, \mathrm{Zn}, \mathrm{Nb}, \mathrm{Ta}$, $\mathrm{Zr}, \mathrm{Hf}$, and $\mathrm{TiO}_{2}$ in $\mathrm{C} 19-\mathrm{r}$, are closer to those of mafic tuff rather than alkalic and silicic tuff [1].

The concentration of $\mathrm{TiO}_{2}$ in $\mathrm{C} 19-\mathrm{r}$ is high (3.88\%). Concentrations of $\mathrm{TiO}_{2}$ in basalt higher than $2.8 \%$ are indicative of high-Ti basalt $[10,11]$. The concentrations of trace elements, including $\mathrm{V}, \mathrm{Co}$, $\mathrm{Cr}, \mathrm{Ni}, \mathrm{Cu}, \mathrm{Zn}, \mathrm{Nb}, \mathrm{Ta}, \mathrm{Zr}$, and Hf, in sample C19-r are closer to those of high-Ti basalt than to those of low-Ti basalt (Table 5). The elemental compositions indicate that roof sample C19-r has a high-Ti basaltic volcanic source.

The REE distribution patterns of C19-r are characterized by positive Eu anomalies and M-REE-type enrichment. This is different from those of normal deposits of Late Permian clay rocks in the Emeishan 
large igneous province, which are generally characterized by weakly negative or no Eu anomalies $[1,51]$, and are the same as those of high-Ti [10] (Figure 17A). To summarize, roof sample C19-r consists of tuffaceous clays and probably has a high-Ti mafic magma source.
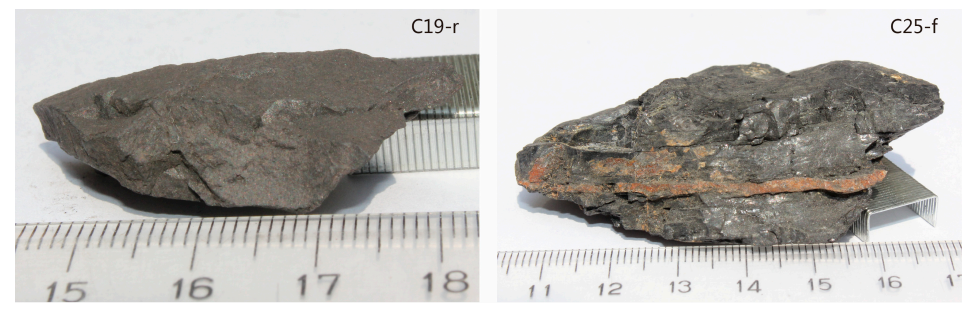

Figure 16. Images of C19-r and C25-f samples collected from the Shiping mine.
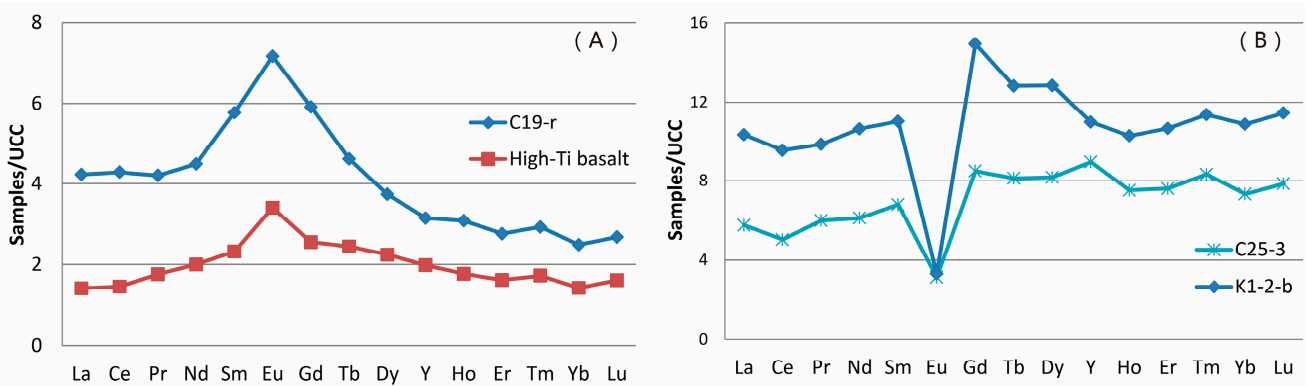

Figure 17. Distribution patterns of REE in the (A) high-Ti basalts [10] and C19-r; and (B) the coal in Lvshuidong [5] and C25-3. REE are normalized by Upper Continental Crust (UCC) [32].

Table 5. The trace element ( $\mu \mathrm{g} / \mathrm{g})$ in sample C19-r compared with high/low Ti basalts [10].

\begin{tabular}{cccccccccccc}
\hline Samples & $\mathbf{V}$ & $\mathbf{C r}$ & $\mathbf{C o}$ & $\mathbf{N i}$ & $\mathbf{C u}$ & $\mathbf{Z n}$ & $\mathbf{G a}$ & $\mathbf{Z r}$ & $\mathbf{N b}$ & $\mathbf{H f}$ & $\mathbf{T a}$ \\
\hline C19-r & 331 & 118 & 16.2 & 36.9 & 278 & 300 & 38.0 & 613 & 91.3 & 13.7 & 5.43 \\
High-Ti Basalt & 374 & 71.0 & 40.3 & 63.5 & 248 & 131 & 23.9 & 391 & 48.5 & 8.51 & 2.97 \\
Low-Ti Basalt & 289 & 230 & 44.5 & 124 & 109 & 90.7 & 19.9 & 129 & 13.4 & 3.05 & 0.773 \\
\hline
\end{tabular}

Coal sample C19-1 has trace element and REE distribution patterns similar to those of normal coal deposits derived from the Kangdian Upland source region [6,7], indicating that sample C19-r is a normal sedimentary rock.

\subsection{C25 Coals and Volcanic Ashes of Alkali Rhyolites}

In the early part of the Late Permian, the volcanic ash had mainly alkalic composition [1,2]. The C25 coals examined in this study are the lowermost coal seam of the Late Permian strata, and these coals are in the same layer as other coals that were affected by alkali volcanics in southwestern China $[4,5,33]$. Moreover, the Shiping mine is within the area of alkali tonstein distribution [16].

High field strength elements, including $\mathrm{Nb}, \mathrm{Ta}, \mathrm{Zr}, \mathrm{Hf}$, and $\mathrm{REE}$, are significantly enriched in $\mathrm{C} 25$ coals, and other elements such as $\mathrm{Sc}, \mathrm{Ti}, \mathrm{V}, \mathrm{Cr}, \mathrm{Co}, \mathrm{Ni}, \mathrm{Cu}$, and $\mathrm{Zn}$ are depleted in $\mathrm{C} 25$ coals $[4,13]$. This characteristic is the same as that of alkali tonsteins and other coals affected by alkali volcanics in southwestern China $[4,5,61]$. This indicates that the C25 coal in the Shiping mine had been subjected to alkalic volcanic ash.

The REE distribution patterns of the C25 coals are characterized by strongly negative Eu anomalies and M-REE-type enrichment, the same as some Chinese alkali granites [62,63], some alkali tonsteins [1] reported in the south of China, and some coals affected by alkali volcanics [5] (Figure 17B). Overall, the $\mathrm{C} 25$ coals have high concentrations of $\mathrm{Nb}$, Ta, Zr, Hf, and REE, which came mainly from alkali volcanics. The origin of these rare metals in the C25 coal present in this study is similar to those in the coals or coal-bearing sedimentary sequences in the surrounding areas [63-67]. 
The floor sample (C25-f) has high concentrations of $\mathrm{Nb}, \mathrm{Ta}, \mathrm{Zr}$, Hf, and REE and has an REE distribution pattern similar to that of the $\mathrm{C} 25$ coal. It is the same as some alkali tonsteins reported in the south of China [1]. These results indicate that floor sample C25-f probably has alkali volcanic origin.

\section{Conclusions}

Sample C19-r does not have distinct stratification, indicating that the roof stratum is not a normal rock. The acicular idiomorphic crystals of apatite and the phenocrysts of Ti-augite coexisting with magnetite in roof sample C19-r are common minerals in basaltic volcanic rock. The REE distribution patterns of C19-r are characterized by positive Eu anomalies and M-REE-type enrichment. All of the above indicates that the roof sample C19-r probably has a basaltic origin.

The concentration of $\mathrm{TiO}_{2}$ in $\mathrm{C} 19-\mathrm{r}$ is high (3.88\%). Concentrations of $\mathrm{TiO}_{2}$ in basalt higher than $2.8 \%$ are indicative of high-Ti basalt. The concentrations of trace elements, including $\mathrm{V}, \mathrm{Co}, \mathrm{Cr}, \mathrm{Ni}, \mathrm{Cu}$, $\mathrm{Zn}, \mathrm{Nb}, \mathrm{Ta}, \mathrm{Zr}$, and Hf, in C19-r are closer to those of high-Ti basalt instead of those of low-Ti basalt. To summarize, roof sample C19-r probably has a high-Ti basaltic origin.

$\mathrm{Nb}, \mathrm{Ta}, \mathrm{Zr}, \mathrm{Hf}$, and REE are significantly enriched in $\mathrm{C} 25$ coals, and other elements such as $\mathrm{Sc}, \mathrm{Ti}$, $\mathrm{V}, \mathrm{Cr}, \mathrm{Co}, \mathrm{Ni}, \mathrm{Cu}$, and $\mathrm{Zn}$ are depleted in $\mathrm{C} 25$ coals. The REE distribution patterns of the $\mathrm{C} 25$ coals are characterized by strongly negative Eu anomalies and M-REE-type enrichment. This indicates that the C25 coals in the Shiping mine were probably affected by alkalic volcanic ashes.

Acknowledgments: This research was supported by the National Key Basic Research Program of China (No. 2014CB238902), the National Natural Science Foundation of China (Nos. 41420104001, 41272182, and U1407207), and the Program for Changjiang Scholars and Innovative Research Team in University (IRT13099). Many thanks are given to Shifeng Dai for his constructive comments, which greatly improved the manuscript quality. We are grateful to the three anonymous reviewers for their careful comments.

Author Contributions: All co-authors participated in the work of this study. Yangbing Luo carried out the mineralogy and geochemistry analyses data. Mianping Zheng helped to design the research and structure of the manuscript.

Conflicts of Interest: The authors declare no conflict of interest.

\section{References}

1. Dai, S.; Wang, X.; Zhou, Y.; Hower, J.C.; Li, D.; Chen, W.; Zhu, X.; Zou, J. Chemical and mineralogical compositions of silicic, mafic, and alkali tonsteins in the late Permian coals from the Songzao Coalfield, Chongqing, Southwest China. Chem. Geol. 2011, 282, 29-44. [CrossRef]

2. Zhou, Y.; Bohor, B.F.; Ren, Y. Trace element geochemistry of altered volcanic ash layers (tonsteins) in Late Permian coal-bearing formations of eastern Yunnan and western Guizhou Provinces, China. Int. J. Coal Geol. 2000, 44, 305-324. [CrossRef]

3. Dai, S.; Li, T.; Seredin, V.V.; Ward, C.R.; Hower, J.C.; Zhou, Y.; Zhang, M.; Song, X.; Song, W.; Zhao, C. Origin of minerals and elements in the Late Permian coals, tonsteins, and host rocks of the Xinde Mine, Xuanwei, eastern Yunnan, China. Int. J. Coal Geol. 2014, 121, 53-78. [CrossRef]

4. Dai, S.; Liu, J.; Ward, C.R.; Hower, J.C.; French, D.; Jia, S.; Hood, M.M.; Garrison, T.M. Mineralogical and geochemical compositions of Late Permian coals and host rocks from the Guxu Coalfield, Sichuan Province, China, with emphasis on enrichment of rare metals. Int. J. Coal Geol. 2015. [CrossRef]

5. Dai, S.; Luo, Y.; Seredin, V.V.; Ward, C.R.; Hower, J.C.; Zhao, L.; Liu, S.; Zhao, C.; Tian, H.; Zou, J. Revisiting the late Permian coal from the Huayingshan, Sichuan, southwestern China: Enrichment and occurrence modes of minerals and trace elements. Int. J. Coal Geol. 2014, 122, 110-128. [CrossRef]

6. Wang, X.; Zhang, Y.; Pan, Y.; Liu, C. The Sedimentary Environment and the Regularity of Coal Accumulation of Late Permian Coals in Southern China; Chongqing University Press: Chongqing, China, 1996; pp. 74-92. (In Chinese)

7. Zhang, Y. The Sedimentary Environment and Coal Accumulation of the Late Permian Coals in Southern Sichuan, China; Guizhou Science and Technology Press: Guiyang, China, 1993; pp. 44-65. (In Chinese)

8. Arbuzov, S.I.; Mezhibor, A.M.; Spears, D.A.; Ilenok, S.S.; Shaldybin, M.V.; Belaya, E.V. Nature of tonsteins in the Azeisk deposit of the Irkutsk Coal Basin (Siberia, Russia). Int. J. Coal Geol. 2016, 153, 99-111. [CrossRef] 
9. Hou, T.; Zhang, Z.; Kusky, T.; Du, Y.; Liu, J.; Zhao, Z. A reappraisal of the high-Ti and low-Ti classification of basalts and petrogenetic linkage between basalts and mafic-ultramafic intrusions in the Emeishan Large Igneous Province, SW China. Ore Geol. Rev. 2011, 41, 133-143. [CrossRef]

10. Xiao, L.; Xu, Y.; Mei, H.; Zheng, Y.; He, B.; Pirajno, F. Distinct mantle sources of low-Ti and high-Ti basalts from the western Emeishan large igneous province, SW China: Implications for plume-lithosphere interaction. Earth Planet. Sci. Lett. 2004, 228, 525-546. [CrossRef]

11. $\mathrm{Xu}, \mathrm{Y}$.; Chung, $\mathrm{S}$. The Emeishan large igneous province: Evidence for mantle plume activity and melting conditions. Geochimica 2001, 30, 1-9.

12. Xu, Y.; Chung, S.; Shao, H.; He, B. Silicic magmas from the Emeishan large igneous province, Southwest China: Petrogenesis and their link with the end-Guadalupian biological crisis. Lithos 2010, 119, 47-60. [CrossRef]

13. Xu, Y.; He, B.; Chung, S.; Menzies, M.A.; Frey, F. A geologic, geochemical, and geophysical consequences of plume involvement in the Emeishan flood-basalt province. Geology 2004, 32, 917-920. [CrossRef]

14. Wang, P.; Ji, D.; Yang, Y.; Zhao, L. Mineralogical compositions of Late Permian coals from the Yueliangtian mine, western Guizhou, China: Comparison to coals from eastern Yunnan, with an emphasis on the origin of the minerals. Fuel 2016, 181, 859-869. [CrossRef]

15. Zhao, L.; Ward, C.R.; French, D.; Graham, I.T. Mineralogical composition of Late Permian coal seams in the Songzao Coalfield, southwestern China. Int. J. Coal Geol. 2013, 116, 208-226. [CrossRef]

16. Zhou, Y. The alkali pyroclastic tonsteins of early stage of late Permian age in southwestern China. Coal Geol Explor. 1999, 27, 5-9. (In Chinese)

17. ASTM International. Test Method for Moisture in the Analysis Sample of Coal and Coke; ASTM Standard D3173-11; ASTM International: West Conshohocken, PA, USA, 2011.

18. ASTM International. Annual Book of ASTM Standards. Test Method for Ash in the Analysis Sample of Coal and Coke; ASTM Standard D3174-11; ASTM International: West Conshohocken, PA, USA, 2011.

19. ASTM International. Test Method for Volatile Matter in the Analysis Sample of Coal and Coke; ASTM Standard D3175-11; ASTM International: West Conshohocken, PA, USA, USA, 2011.

20. ASTM International. Test Methods for Total Sulfur in the Analysis Sample of Coal and Coke; ASTM Standard D3177-02; ASTM International: West Conshohocken, PA, USA, USA, 2002.

21. ASTM International. Standard Test Method for Forms of Sulfur in Coal; ASTM Standard D2492-02; ASTM International: West Conshohocken, PA, USA, 2002.

22. ASTM International. Standard Practice for Preparing Coal Samples for Microscopical Analysis by Reflected Light; ASTM Standard D2797/D2797M-11a; ASTM International: West Conshohocken, PA, USA, 2011.

23. ASTM International. Standard Test Method for Total Fluorine in Coal and Coke by Pyrohydrolytic Extraction and Ion Selective Electrode or Ion Chromatograph Methods; ASTM Standard D5987-96; ASTM International: West Conshohocken, PA, USA, 2002.

24. Li, X.; Dai, S.; Zhang, W.; Li, T.; Zheng, X.; Chen, W. Determination of As and Se in coal and coal combustion products using closed vessel microwave digestion and collision/reaction cell technology (CCT) of inductively coupled plasma mass spectrometry (ICP-MS). Int. J. Coal Geol. 2014, 124, 1-4. [CrossRef]

25. ASTM International. Standard Classification of Coals by Rank; ASTM Standard D388-12; ASTM International: West Conshohocken, PA, USA, 2012.

26. Standardization Administration of China; General Administration of Quality Supervision, Inspection and Quarantine of the China. Classification for Quality of Coal-Part 1: Ash; Chinese National Standard GB/T 15224.1-2004; Standard Press of China: Beijing, China, 2004. (In Chinese)

27. Dai, S.; Ren, D.; Chou, C.-L.; Finkelman, R.B.; Seredin, V.V.; Zhou, Y. Geochemistry of trace elements in Chinese coals: A review of abundances, genetic types, impacts on human health, and industrial utilization. Int. J. Coal Geol. 2012, 94, 3-21. [CrossRef]

28. Ketris, M.; Yudovich, Y.E. Estimations of clarkes for carbonaceous biolithes: World averages for trace element contents in black shales and coals. Int. J. Coal Geol. 2009, 78, 135-148. [CrossRef]

29. Dai, S.; Seredin, V.V.; Ward, C.R.; Hower, J.C.; Xing, Y.; Zhang, W.; Song, W.; Wang, P. Enrichment of U-Se-Mo-Re-V in coals preserved within marine carbonate successions: Geochemical and mineralogical data from the Late Permian Guiding Coalfield, Guizhou, China. Miner. Deposita 2015, 50, 159-186. [CrossRef]

30. Grigoriev, N. Chemical Element Distribution in the Upper Continental Crust; UB RAS: Ekaterinburg, Russia, 2009; p. 382. (In Russian) 
31. Seredin, V.V.; Dai, S. Coal deposits as potential alternative sources for lanthanides and yttrium. Int. J. Coal Geol. 2012, 94, 67-93. [CrossRef]

32. Taylor, S.R.; McLennan, S.M. The Continental Crust: Its Composition and Evolution; Blackwell: Oxford, UK, 1985; p. 312.

33. Dai, S.F.; Chekryzhov, I.Y.; Seredin, V.V.; Nechaev, V.P.; Graham, I.T.; Hower, J.C.; Ward, C.R.; Ren, D.Y.; Wang, X.B. Metalliferous coal deposits in East Asia (Primorye of Russia and South China): A review of geodynamic controls and styles of mineralization. Gondwana Res. 2016, 29, 60-82. [CrossRef]

34. Dai, S.; Graham, I.T.; Ward, C.R. A review of anomalous rare earth elements and yttrium in coal. Int. J. Coal Geol. 2016, 159, 82-95. [CrossRef]

35. Dai, S.; Zhou, Y.; Zhang, M.; Wang, X.; Wang, J.; Song, X.; Jiang, Y.; Luo, Y.; Song, Z.; Yang, Z.; et al. A new type of $\mathrm{Nb}(\mathrm{Ta})-\mathrm{Zr}(\mathrm{Hf})-\mathrm{REE}-\mathrm{Ga}$ polymetallic deposit in the late Permian coal-bearing strata, eastern Yunnan, southwestern China: Possible economic significance and genetic implications. Int. J. Coal Geol. 2010, 83, 55-63. [CrossRef]

36. Liu, J.; Yang, Z.; Yan, X.; Ji, D.; Yang, Y.; Hu, L. Modes of occurrence of highly-elevated trace elements in superhigh-organic-sulfur coals. Fuel 2015, 156, 190-197. [CrossRef]

37. Dai, S.; Ren, D.; Zhou, Y.; Chou, C.-L.; Wang, X.; Zhao, L.; Zhu, X. Mineralogy and geochemistry of a superhigh-organic-sulfur coal, Yanshan Coalfield, Yunnan, China: Evidence for a volcanic ash component and influence by submarine exhalation. Chem. Geol. 2008, 255, 182-194. [CrossRef]

38. Dai, S.; Wang, X.; Chen, W.; Li, D.; Chou, C.-L.; Zhou, Y.; Zhu, C.; Li, H.; Zhua, X.; Xing, Y.; et al. A high-pyrite semianthracite of Late Permian age in the Songzao Coalfield, southwestern China: Mineralogical and geochemical relations with underlying mafic tuffs. Int. J. Coal Geol. 2010, 83, 430-445. [CrossRef]

39. Dai, S.; Ren, D.; Hou, X.; Shao, L. Geochemical and mineralogical anomalies of the late Permian coal in the Zhijin coalfield of southwest China and their volcanic origin. Int. J. Coal Geol. 2003, 55, 117-138. [CrossRef]

40. Dai, S.; Chou, C.-L.; Yue, M.; Luo, K.; Ren, D. Mineralogy and geochemistry of a Late Permian coal in the Dafang Coalfield, Guizhou, China: Influence from siliceous and iron-rich calcic hydrothermal fluids. Int. J. Coal Geol. 2005, 61, 241-258. [CrossRef]

41. Zhao, L.; Ward, C.R.; French, D.; Graham, I.T. Mineralogy of the volcanic-influenced Great Northern coal seam in the Sydney Basin, Australia. Int. J. Coal Geol. 2012, 94, 94-110. [CrossRef]

42. Ruppert, L.F.; Moore, T.A. Differentiation of volcanic ash-fall and water-borne detrital layers in the Eocene Senakin coal bed, Tanjung Formation, Indonesia. Org. Geochem. 1993, 20, 233-247. [CrossRef]

43. Spears, D.A. The origin of tonsteins, an overview, and links with seatearths, fireclays and fragmental clay rocks. Int. J. Coal Geol. 2012, 94, 22-31. [CrossRef]

44. Dan, W.; Wang, Q.; Wang, X.; Liu, Y.; Wyman, D.A.; Liu, Y. Overlapping Sr-Nd-Hf-O isotopic compositions in Permian mafic enclaves and host granitoids in Alxa Block, NW China: Evidence for crust-mantle interaction and implications for the generation of silicic igneous provinces. Lithos 2015, 230, 133-145. [CrossRef]

45. Liu, W.; Zhang, J.; Sun, T.; Zhou, L.; Liu, A. Low-Ti iron oxide deposits in the Emeishan large igneous province related to low-Ti basalts and gabbroic intrusions. Ore Geol. Rev. 2015, 65, 180-197. [CrossRef]

46. Shellnutt, J.G.; Lee, T.; Yang, C.; Hu, S.; Wu, J.; Iizuka, Y. A mineralogical investigation of the Late Permian Doba gabbro, southern Chad: Constraints on the parental magma conditions and composition. J. Afr. Earth Sci. 2016, 114, 13-20. [CrossRef]

47. Mathison, C.I. Magnetites and ilmenites in the Somerset dam layered basic intrusion, southeastern Queensland. Lithos 1975, 8, 93-111. [CrossRef]

48. Hou, M.; Deng, M.; Zhang, B.; Wang, W.; Li, X.; Wang, W.; Pei, S.; Yang, Y. A major Ti-bearing mineral in Emeishan basalts: The occurrence, characters and genesis of sphene. Acta Petrol. Sin. 2011, 27, 2487-2499. (In Chinese)

49. Liu, X.; Cai, Y.; Lu, Q.; Tao, Z.; Zhao, F.; Cai, F.; Li, C.; Song, X. Actual traces of mantle fluid from alkali-rich porphyries in western Yunnan, and associated implications to metallogenesis. Earth Sci. Front. 2010, 17, 114-136. (In Chinese)

50. Du, W.; Han, B.; Zhang, W.; Liu, Z. The discovery of peridotite xenoliths and megacrysts in Jining, Inner Mongolia. Acta Petrol. Mineral. 2016, 25, 13-24. (In Chinese) [CrossRef] [PubMed]

51. He, B.; Xu, Y.; Zhong, Y.; Guan, J. The Guadalupian-Lopingian boundary mudstones at Chaotian (SW China) are clastic rocks rather than acidic tuffs: Implication for a temporal coincidence between the end-Guadalupian mass extinction and the Emeishan volcanism. Lithos 2010, 119, 10-19. [CrossRef] 
52. Dai, S.; Hower, J.C.; Ward, C.R.; Guo, W.; Song, H.; O'Keefe, J.M.K.; Xie, P.; Hood, M.M.; Yan, X. Elements and phosphorus minerals in the middle Jurassic inertinite-rich coals of the Muli Coalfield on the Tibetan Plateau. Int. J. Coal Geol. 2015, 144-145, 23-47. [CrossRef]

53. Zhao, L.; Graham, I. Origin of the alkali tonsteins from southwest China: Implications for alkaline magmatism associated with the waning stages of the Emeishan Large Igneous Province. Aust. J. Earth Sci. 2016, 63, 123-128. [CrossRef]

54. Dai, S.; Yang, J.; Ward, C.R.; Hower, J.C.; Liu, H.; Garrison, T.M.; French, D.; O'Keefe, J.M.K. Geochemical and mineralogical evidence for a coal-hosted uranium deposit in the Yili Basin, Xinjiang, northwestern China. Ore Geol. Rev. 2015, 70, 1-30. [CrossRef]

55. Dai, S.; Li, T.; Jiang, Y.; Ward, C.R.; Hower, J.C.; Sun, J.; Liu, J.; Song, H.; Wei, J.; Li, Q.; et al. Mineralogical and geochemical compositions of the Pennsylvanian coal in the Hailiushu Mine, Daqingshan Coalfield, Inner Mongolia, China: Implications of sediment-source region and acid hydrothermal solutions. Int. J. Coal Geol. 2015, 137, 92-110. [CrossRef]

56. Johnston, M.N.; Hower, J.C.; Dai, S.; Wang, P.; Xie, P.; Liu, J. Petrology and Geochemistry of the Harlan, Kellioka, and Darby Coals from the Louellen 7.5-Minute Quadrangle, Harlan County, Kentucky. Minerals 2015, 5, 894-918. [CrossRef]

57. Hower, J.C.; Eble, C.F.; O’Keefe, J.M.K.; Dai, S.; Wang, P.; Xie, P.; Liu, J.; Ward, C.R.; French, D. Petrology, Palynology, and Geochemistry of Gray Hawk Coal (Early Pennsylvanian, Langsettian) in Eastern Kentucky, USA. Minerals 2015, 5, 592-622. [CrossRef]

58. Dai, S.; Zhang, W.; Ward, C.R.; Seredin, V.V.; Hower, J.C.; Li, X.; Song, W.; Wang, X.; Kang, H.; Zheng, L.; et al. Mineralogical and geochemical anomalies of Late Permian coals from the Fusui Coalfield, Guangxi Province, southern China: Influences of terrigenous materials and hydrothermal fluids. Int. J. Coal Geol. 2013, 105, 60-84. [CrossRef]

59. Dai, S.; Wang, P.; Ward, C.R.; Tang, Y.; Song, X.; Jiang, J.; Hower, J.C.; Li, T.; Seredin, V.V.; Wagner, N.J.; et al. Elemental and mineralogical anomalies in the coal-hosted Ge ore deposit of Lincang, Yunnan, southwestern China: Key role of $\mathrm{N}_{2}-\mathrm{CO}_{2}$-mixed hydrothermal solutions. Int. J. Coal Geol. 2015, 152, 19-46. [CrossRef]

60. Dai, S.; Liu, J.; Ward, C.R.; Hower, J.C.; Xie, P.; Jiang, Y.; Hood, M.M.; O’Keefe, J.M.K.; Song, H. Petrological, geochemical, and mineralogical compositions of the low-Ge coals from the Shengli Coalfield, China: A comparative study with Ge-rich coals and a formation model for coal-hosted Ge ore deposit. Ore Geol. Rev. 2015, 71, 318-349. [CrossRef]

61. Zhuang, X.; Su, S.; Xiao, M.; Li, J.; Alastuey, A.; Querol, X. Mineralogy and geochemistry of the Late Permian coals in the Huayingshan coal-bearing area, Sichuan Province, China. Int. J. Coal Geol. 2012, 94, 271-282. [CrossRef]

62. Zhao, Z.; Zhou, L. Geochemistry of rare earth elements in some Chinese alkali-rich in trusive rocks. Sci. China Ser. B 1994, 24, 1109-1120. (In Chinese)

63. Dai, S.; Xie, P.; Jia, S.; Ward, C.R.; Hower, H.C.; Yan, X.; French, D. Enrichment of U-Re-V-Cr-Se and rare earth elements in the Late Permian coals of the Moxinpo Coalfield, Chongqing, China: Genetic implications from geochemical and mineralogical data. Ore Geol. Rev. 2017, 80, 1-17. [CrossRef]

64. Zhao, L.; Dai, S.; Graham, I.T.; Li, X.; Liu, H.; Song, X.; Hower, J.C.; Zhou, Y. Cryptic sediment-hosted critical element mineralization from eastern Yunnan Province, southwestern China: Mineralogy, geochemistry, relationship to Emeishan alkaline magmatism and possible origin. Ore Geol. Rev. 2017, 80, 116-140. [CrossRef]

65. Dai, S.; Yan, X.; Ward, C.R.; Hower, J.C.; Zhao, L.; Wang, X.; Zhao, L.; Ren, D.; Finkelman, R.B. Valuable elements in Chinese coals: A review. Int. Geol. Rev. 2016. [CrossRef]

66. Hower, J.C.; Eble, C.F.; Dai, S.; Belkin, H.E. Distribution of rare earth elements in eastern Kentucky coals: Indicators of multiple modes of enrichment? Int. J. Coal Geol. 2016, 160-161, 73-81. [CrossRef]

67. Zhao, L.; Dai, S.; Graham, I.; Wang, P. Clay mineralogy of coal-hosted Nb-Zr-REE-Ga mineralized beds from Late Permian strata, eastern Yunnan, SW China: Implications for palaeotemperature and origin of the micro-quartz. Minerals 2016, 6, 45. [CrossRef]

(C) 2016 by the authors; licensee MDPI, Basel, Switzerland. This article is an open access article distributed under the terms and conditions of the Creative Commons Attribution (CC-BY) license (http://creativecommons.org/licenses/by/4.0/). 